\title{
Ctenophorus spinodomus sp. nov., a New Species of Dragon Lizard (Squamata: Agamidae) from Triodia Mallee Habitat of Southeast Australia
}

\author{
Ross A. Sadlier ${ }^{1,2}$ D, Don Colgan ${ }^{1}$ (D) Cecilie A. Beatson ${ }^{2}$ (iD and Hal G. Cogger ${ }^{1}$ \\ ${ }^{1}$ Australian Museum Research Institute, \\ Australian Museum, 1 William Street. Sydney NSW 2010, Australia \\ ${ }^{2}$ Outwest Reptile Consulting Services, \\ Montefiores Street, Wellington NSW 2820, Australia
}

\begin{abstract}
Research into geographic variation in the agamid lizard Ctenophorus fordi supports a pattern of regional lineage diversity identified in earlier genetic studies, and provides new information on differences in morphology diagnostic of these lineages. One of the most genetically divergent and morphologically distinctive of these lineages is that consisting of populations from Triodia Mallee habitat of the red sandplains of inland southeast Australia. Populations from this region are the sister lineage to all other "C. fordi", a suite of four genetically regionally discrete lineages distributed across the arid inland of southern Australia. They can be distinguished by a unique black " $T$ " shaped chest pattern in adult males which, in combination with certain features of body proportions and scalation, diagnose the lineage from all other " $C$. fordi". On the strength of these differences we describe populations belonging to this lineage as a new species, Ctenophorus spinodomus sp. nov. This new species is highly restricted in the habitat it occupies, and its ecology tied to a reliance on the presence of Triodia hummock grass groundcover (spinifex) for shelter, foraging and social interactions. It appears to be most abundant in areas of extensive and healthy Triodia that develop 20-50 years post-burn, and as a consequence too many or too few fires can both have negative impacts on the suitability of hummock grass groundcover for this species. Mallee habitat in southeast Australia is fragmented, and large fires in the smaller isolated areas of habitat could result in loss of suitable habitat for the species, resulting in localized extinction with no opportunity for recruitment. These factors in combination with ongoing loss of habitat place the remaining populations of C. spinodomus sp. nov. at a high level of vulnerability.
\end{abstract}

\section{Introduction}

The agamid lizard Amphibolurus fordi was described by Storr in 1965 from populations in inland southwest Western Australia as part of a review of the Amphibolurus maculatus species group (Storr, 1965). It was named for Julian Ford, accomplished Western Australian naturalist and collector of the holotype, and was initially called Ford's Dragon. The name fordi along with the common name Mallee Dragon was subsequently applied in a broader geographical sense by Cogger (1975) to include the east Australian populations of what was previously regarded as Amphibolurus maculatus (Cogger, 1967). This concept of the species having a broad distribution across the arid interior of southern Australia, from near Kalgoorlie in Western Australia to central-western New South Wales (Cogger, 1975 and subsequent editions) has remained for the past 40 years.

Keywords: Agamidae; dragon lizard; Ctenophorus; Triodia Mallee; taxonomy; new species; Eastern Mallee Dragon

Taxonomic registration: (LSID publication) http://zoobank.org/07502465-79E0-44F2-8A51-EC4F78DE208B

Corresponding author: Ross A. Sadlier ross.sadlier@bigpond.com

Received: 20 December 2018 Accepted: 29 July 2019 Published: 28 August 2019 (in print and online simultaneously)

Publisher: The Australian Museum, Sydney, Australia (a statutory authority of, and principally funded by, the NSW State Government)

Citation: Sadlier, Ross A., Don Colgan, Cecilie A. Beatson, and Hal G. Cogger. 2019. Ctenophorus spinodomus sp. nov., a new species of dragon lizard

(Squamata: Agamidae) from Triodia Mallee habitat of southeast Australia. Records of the Australian Museum 71(5): $199-215$.

https://doi.org/10.3853/j.2201-4349.71.2019.1700

Copyright: (C) 2019 Sadlier, Colgan, Beatson, Cogger. This is an open access article licensed under a Creative Commons

Attribution 4.0 International License (CC BY 4.0), which permits unrestricted use, distribution, and reproduction in any

medium, provided the original authors and source are credited. 
Cogger undertook detailed studies of the ecology of the eastern-most populations in central-west New South Wales as the subject of a doctoral thesis (Cogger, 1969), later publishing on the thermal preferences (1974) and reproductive cycles and social behaviour (1978) of the species. His studies identified the presence of Triodia hummock grass as a crucial component of the species' environment in the population studied, a trait found to be broadly applicable to populations inhabiting the red sand plains of inland southeast Australia. Houston (1978) in his illustrated treatise of the agamid and varanid lizards of South Australia identified three races of Amphibolurus fordi in the state, based primarily on variation in colouration, particularly the pattern of dark markings on the throat and chest of adult males. In this work Houston identified a race in the arid northern interior of the state (presumably contiguous with the Western Australian populations), one restricted to the Eyre Peninsula, and one from the southeast of the state (presumably contiguous with the inland New South Wales population). In reference to comment made by Cogger on the habitat specificity of the species in New South Wales, Houston stated that colonies of the northern race also occupied bluebush and tussock grass habitat.

Populations in the far northwest of New South Wales (Swan, 1990; Swan et al., 2004, 2017) and the adjacent areas of far southwest Queensland (Covacevich \& Couper, 1991) have also been referred to as $C$. fordi for a number of years, but the identity of these populations with respect to their morphology and biology lay largely unknown, as did their relationship to the populations in central New South Wales or those in adjacent areas of inland northern South Australia. Field studies undertaken at Sturt National Park by the Australian Museum in collaboration with the Australian Herpetological Society in the period 1997-1998 provided the samples required to undertake detailed morphological and genetic studies into the taxonomic status of the population far northwest New South Wales. Further, these field studies identified the population in this region as able to occupy red-sand plain dune systems independent of the presence of Triodia hummock grass, as also stated earlier by Houston (1978) for the northern South Australian populations, and in sharp contrast to the dependence on Triodia reported by Cogger for populations in central-west New South Wales. The differences in habitat preference provided by these field studies called into question the conspecificity of these eastern populations, and a genetic study of Ctenophorus fordi populations across the species range was undertaken to assess the extent of differentiation between populations in New South Wales, and how this related to the morphological races earlier identified by Houston and to the type population in southwest Western Australia.

The results of our morphological and genetic investigations into the easternmost populations of $C$. fordi dependent on Triodia Mallee habitat of inland southeast Australia revealed it to be highly differentiated in morphology and forming a discrete genetic group that is the sister to all other " $C$. fordi". Further, it found $C$. fordi to be a composite of distinct lineages, each falling discretely within a single major geographical biome.

In the interim period since our studies commenced an independent genetic study of Ctenophorus maculatus and related species, including fordi, has been undertaken by Edwards et al. (2015) to determine the evolutionary history of signalling and associated morphological traits in this group of agamid lizards. The lineages retrieved by this study were broadly complementary with ours, lending further support for these as geographically discrete evolutionary entities.

The primary purpose of the results presented here is the formal taxonomic recognition of the lineage from Triodia Mallee habitat of inland southeast Australia identified by our genetic study. The formal treatment of the other lineages found within C. fordi will soon be presented by Edwards \& Hutchinson (pers. comm.) as part of an overall revision of Ctenophorus maculatus and related species.

\section{Materials and methods}

Genetic study. We used the CTAB method (Saghai-Maroof et al., 1984) to extract DNA from small samples of tail tips for 25 specimens from 11 individual locations across the range of C. fordi (Appendix 1), and from an individual of Ctenophorus maculatus s.s. for outgroup comparison. The final DNA pellet was dissolved in $100 \mu \mathrm{L}$ TE buffer.

PCR was conducted with Red Hot ${ }^{\mathrm{TM}}$ thermostable DNA polymerase (Advanced Biotechnologies, Leatherhead, Surrey) according to the manufacturer's protocol in a reaction volume of $50 \mu \mathrm{L} 0.05 \mathrm{~mm}$ dNTPs, $2.5 \mathrm{~mm} \mathrm{MgCl}_{2}, 12.5$ pmol of each primer and $1 \mu \mathrm{L}$ of a dilution (usually 1 in 25 ) of the DNA sample. The cycling protocol was an initial denaturation step of $94^{\circ} \mathrm{C}$ for $2 \mathrm{~min}$, followed by 10 cycles of $94^{\circ} \mathrm{C}$ for $30 \mathrm{sec}$ annealing for $30 \mathrm{sec}, 72^{\circ} \mathrm{C}$ for $1 \mathrm{~min}$, and 23 cycles of $\left(94^{\circ} \mathrm{C}\right.$ for $30 \mathrm{sec}$, annealing for $30 \mathrm{sec}, 72^{\circ} \mathrm{C}$ for $1 \mathrm{~min}$ with a final extension step of $72^{\circ} \mathrm{C}$ for $10 \mathrm{~min}$.

Three segments of the mitochondrial genome were amplified using the following sets of primers. $12 \mathrm{~S}$ ribosomal RNA-1478 (5'-TGACTGCAGAGGGTGA CGGGCGGTGTGT-3') (Kocher et al., 1989) and12S rDNAl (5'-AAAAAGCTTCAAACTGGGATTAGATACCCC-3') (Nedbal et al., 1994); 16S ribosomal RNA-16Sar (5'-CGCCTGTTTAACAAAAACAT) and 16Sbr (5'-CCG GTCTGAACTCAGATCACGT-3') both from Simon et al. (1994); and part of NADH dehydrogenase subunit 4 ND4 (5'-TGACTACCAAAGCTCATGTAGAAGC-3'), the tRNA-Histidine gene, the tRNA-Serine gene part of the tRNA Leucine 2 gene (5'-TTTTACTTGGAT TTGCACCA3') both from O'Connor and Moritz (2003) as modified from Arevalo et al. (1994). An internal primer was used to complete the sequence of this segment which was ND4INTF (5'-CCHCCDWCHATYAAYHTHATAGGAGA). The annealing temperatures were $52^{\circ} \mathrm{C}$ for the $12 \mathrm{~S}$ rRNA and $16 \mathrm{~S}$ rRNA segments and $52-54^{\circ} \mathrm{C}$ for the NAD/Tleu segment.

Reaction products were resolved on $2 \%$ agarose gels containing ethidium bromide. All single band products were purified using the QIAquick ${ }^{\mathrm{TM}}$ PCR Purification Kit (Qiagen). Products were sequenced in both directions using each of the original primers individually with the DyeDeoxy ${ }^{\mathrm{TM}}$ Terminator sequencing method (Big Dye ${ }^{\mathrm{TM}}$ version 3.0) according to the manufacturer's protocols except that the reactions were scaled down to $10 \mu \mathrm{L}$, containing 2 $\mu \mathrm{L}$ of Big Dye. After purification (by ethanol precipitation), the sequencing reactions were run on an Applied Biosystems $(\mathrm{ABI}){ }^{\circledR} 310$ DNA Sequencing System. The consensus sequence for each individual was obtained using Sequence Navigator.

Alignments of the DNA sequences were made using the default parameters in ClustalX (Thompson et al., 1997). 
BioEdit (Hall, 1999) was used for sequence inspection, file formatting and dataset concatenation. Maximum likelihood (ML) analyses were conducted at the CIPRES Science Gateway (Miller et al., 2010) using RAxML (Stamatakis et al., 2008), assuming no invariable sites, estimating base frequencies, and assessing node support by rapid bootstrap with the number of replicates determined by the software, according to the MRE-based bootstopping criterion (Pattengale et al., 2010). The data from the three segments of the mitochondrial genome were treated as independent partitions in the analysis.

MEGA 7 Molecular Evolutionary Genetics Analysis version 7.0 (Kumar et al., 2016) was used for the calculation of genetic distances.

Morphological study. We examined 149 specimens from over 30 locations across the range of the genetic lineages included under C. fordi (Appendix 2) for the mensural and scalation characters listed below.

Scalation. Upper labial scale rows (ULS) - number of scale rows along the upper jaw from 1st scale behind the rostral to the last obviously enlarged scale posteriorly; subdigital lamellae of the 4th toe (SDL) counted from the apex of the 3rd and 4th toes of the hindfoot to the last scale at the claw; femoral pore scales (FPS) the number of pore bearing scales along the femur of the hindlimb counted as left and right values from the midline between the hindlimbs to the furthest extent along the hindlimb approaching the tibia. Bilateral scalation characters were scored on both sides and the mean value used in the analysis and description of each species.

Measurements. Snout to vent length (SVL) - measured from tip of the snout to the posterior edge of the anal scales; axilla to groin length (AGL) - measured from posterior edge at base of forelimb to anterior edge at base of hindlimb; tail length (TLL) - measured from the posterior edge of the anal scales to the tip of the tail on complete original tails only; hindlimb length (HLL) - measured from the middle of the base of the hindlimb to tip of fourth toe (not including the nail); head length (HDL) - measured down the midline from the back of the skull to the tip of the snout at mid rostrum; head width (HDW) - measured across the head from the posterior edge of the last upper labial scale either side. Body measurements presented in the diagnosis are for adult individuals only, as determined by reproductive maturity. Head length, axilla to groin length, tail length and hindlimb length are expressed as a percentage of snout to vent length, and head width is expressed as a percentage of head length.

Variation between regionally discrete "Groups" that each comprised clusters of populations belonging to a distinct genetic clade, or fell within the regional boundaries of a clade, was assessed using independent two sample t-tests for all morphometric and scalation characters. Only characters with a high $\mathrm{P}$-value approaching $\mathrm{P} \leq 0.001$ (denoted in text with a single asterisk * after character state) are considered as likely to reflect unambiguous species level differences (less than one in a thousand chance of being wrong), while those with a $\mathrm{P}>0.001$ but less than $<0.01$ (denoted in text with a double asterisk $* *$ ) are suggestive of a significant trend in character difference. Samples from locations in geographically disjunct regions contained within the geographic range of a lineage identified by the genetic study were also tested for internal geographic variation, i.e. populations from central-west NSW vs populations from southwest NSW. In the absence of internal geographic variation samples from locations within the geographic range of the lineages identified by the genetic study were then pooled for the purpose of cross-comparison between lineages. All pooled populations were tested for sexual dimorphism in scalation and mensural characters using independent two-sample t-tests. Sexual dimorphism was found to be present at varying levels of significance, and as such inter and intra population level differences are presented separately for each sex.

We follow the lead of Pepper et al. (2011) in adopting the approach of De Queiroz (2007) that the common primary definition of a species is a group of metapopulations that are evolving independently. Further, we concur that the diagnosis of "cryptic" taxa, separately-evolving entities that have not differentiated morphologically from close relatives, is problematic. The lineages identified by the molecular data residing under $C$. fordi show both divergent evolution and lack of mixing of gene pools, demonstrating they each individually comprise a metapopulation that no longer engages in reticulate evolution with neighbouring allopatric or parapatric populations belonging to other genetic lineages, despite their close (relative) proximity in some cases. This is a scenario similar to that presented by Pepper et al. (2011) for four of the six species of diplodactylid geckos in the genus Rhynchoedura, once considered a single widespread species throughout the arid interior of much of the continent.

\section{Results}

Genetic study. The optimal overall ML tree had a $\ln$ likelihood of -4047.75 . The number of rapid bootstrap replicates was 204, as determined by the MRE bootstopping criterion. Analyses of the data set of the mitochondrial ND4, $12 \mathrm{~S}$ and $16 \mathrm{~S}$ genes, individually and combined, identified five well-supported branches exclusive of the outgroup (Fig. 1) as follows:

- [Group 1] populations from central-west and southwest New South Wales (NSW).

- [Group 2] populations from inland southwest Western Australia (WA).

- [Group 3] populations from the Strzelecki and Tarari dune systems of northeast South Australia (SA) and adjacent northwest NSW, and east Gawler dune system of inland central SA.

- [Group 4] populations from the Great Victoria Desert of central-west SA.

- [Group 5] populations from Eyre Peninsula in SA.

All groups comprise regionally discrete clusters of populations (Fig. 2), usually from two or more locations, though one, Group 4 from the Great Victoria Desert, is represented by a single population. Group 1 populations from central-west and southwest NSW comprise a highly divergent strongly supported monophyletic lineage. The basal dichotomy in the phylogeny is for the Group 1 populations as the sister to all other groups currently under C. fordi, but with low support for this relationship $(<50 \%)$. Group 2 populations from inland southwest WA (hereafter 


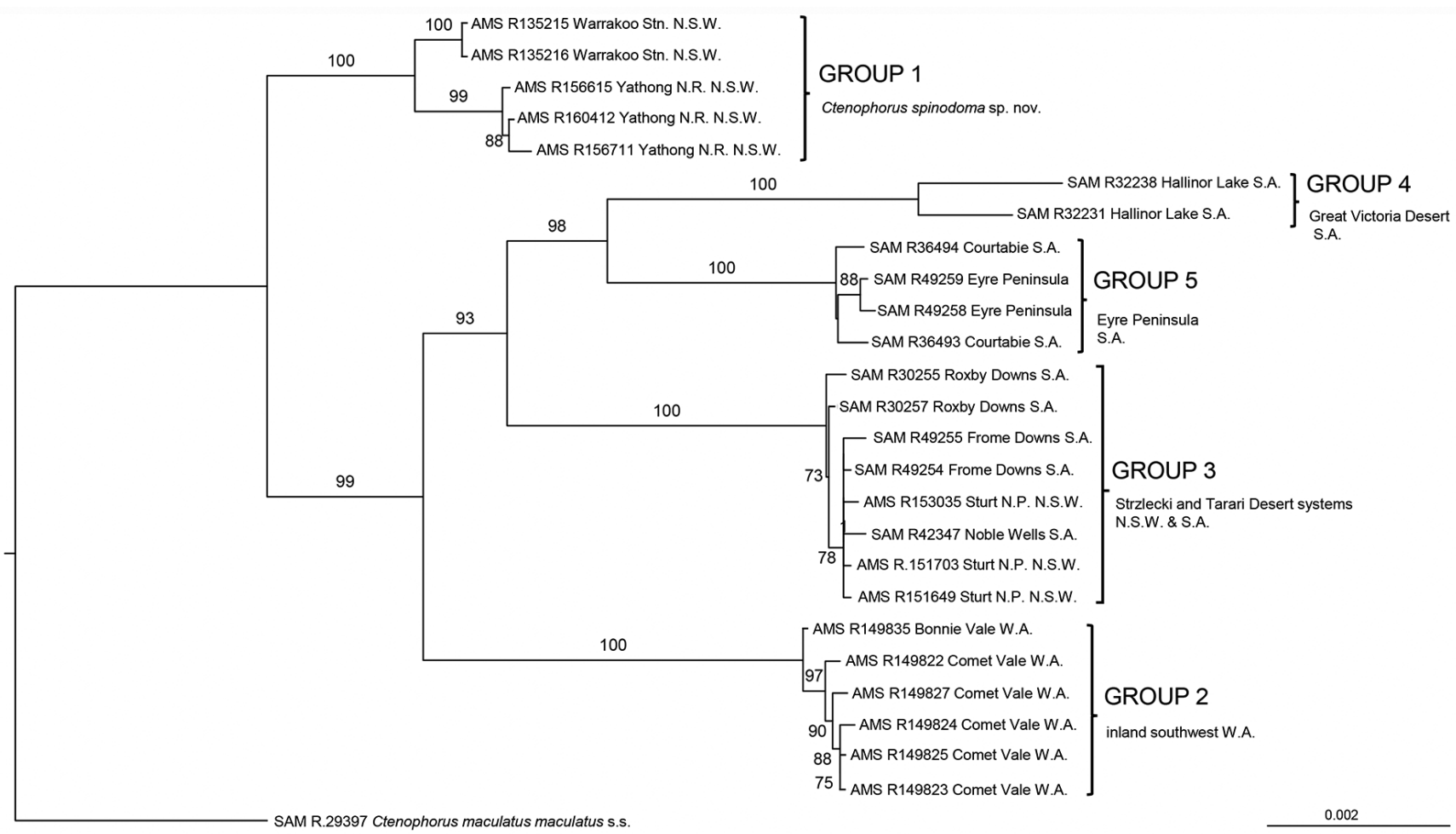

Figure 1. Phylogeny of populations from across the range formerly all included under Ctenophorus fordi derived from sequence data for the concatenated 12S, 16S and ND4 mitochondrial genes, maximum likelihood, partitioned analysis.

referred to as $C$. fordi s.s.) were resolved as the sister to the remaining groups that included Group 3 populations from the desert systems of inland of northeast SA and adjacent northwest NSW (hereafter referred to as C.fordi Strzelecki) + the Group 4 population from the Great Victoria Desert of central-west SA (hereafter referred to as C.fordi GVD) + the Group 5 population from the Eyre Peninsula in SA(hereafter referred to as $C$.fordi Eyre). Within this latter cluster Group 3 was retrieved as the sister to Group $4+$ Group 5, with high support values at all three nodes.

The level of genetic differentiation between groups for various combinations of pairwise comparisons of groups was high (Table 1). Group 1 had an average pairwise distance of $0.057( \pm 0.005)$ for all mitochondrial genes combined and $0.094( \pm 0.010)$ for ND4 alone when compared to Groups 2, 3, 4 and 5 combined; Group 2 had an average pairwise distance of $0.058( \pm 0.006)$ for all mitochondrial genes combined and $0.092( \pm 0.010)$ for ND4 alone when compared to Groups 3, 4 and 5 combined. These levels of genetic differentiation approached that between the outgroup $C$. maculatus and all groups combined, with an average pairwise distance of $0.063( \pm 0.006)$ for all mitochondrial genes combined and $0.106( \pm 0.012)$ for ND4 alone. Individual average net pairwise comparisons between Groups 3, 4 and 5 for all mitochondrial genes combined and for ND4 only were in most cases only marginally different, ranging from 0.068 to 0.046 for all mitochondrial genes combined, and 0.107 to 0.065 for ND4 alone.

The level of differentiation obtained in most pairwise mitochondrial ND4 gene comparisons was equal to or greater than those reported between recognized species of Australian lizards in studies utilizing this gene to define species boundaries. McLean et al. (2013) cited corrected mtDNA
(ND4) net sequence divergence of $7.1-9.6 \%$ between the recently described agamid Ctenophorus mirrityana from far western NSW and populations of Ctenophorus decresii in SA. Similar levels of sequence divergence have been reported between well-established species of skinks (Stuart-Fox et al., 2002), and for major clade divergence within taxa subsequently recognized to be a composite of species (Stuart-Fox et al., 2002; Mousalli et al., 2009). Even the lower values observed in some pairwise comparisons between our groups were of a magnitude similar to those reported for recently described species of skink in the genus Egernia (Doughty et al., 2011).

Our results are consistent with the genetic study of Edwards et al. (2015) in identifying the Group 1 populations from central-west and southwest NSW as highly differentiated from all other populations currently residing under $C$. fordi, and in retrieving the remaining genetic groupings as a well-supported monophyletic group, hereafter referred to collectively as the $C$. ford $i$ genetic lineages. However, the topology of the four lineages that remain under $C$. fordi differs between the two studies. Ours placed these four lineages in a well-supported hierarchy (Group 2 (Group 3 (Group $4+5)$ )), whereas Edwards et al. placed these lineages within two subgroups, one comprising populations from within the geographic ranges of our Group 3 and Group 4, with a high level of support for this sister taxa relationship, the other populations within the geographic ranges of our Group 5 and Group 2, but with a low level of support for this relationship. In that study the species Ctenophorus femoralis from the coastal WA was retrieved as the sister to these two subgroups, but with only low-moderate support. This species was not considered in our study, and its placement, albeit tenuous, lends further support to $C$. fordi being polyphyletic. The study of Edwards et al. (2015) also 


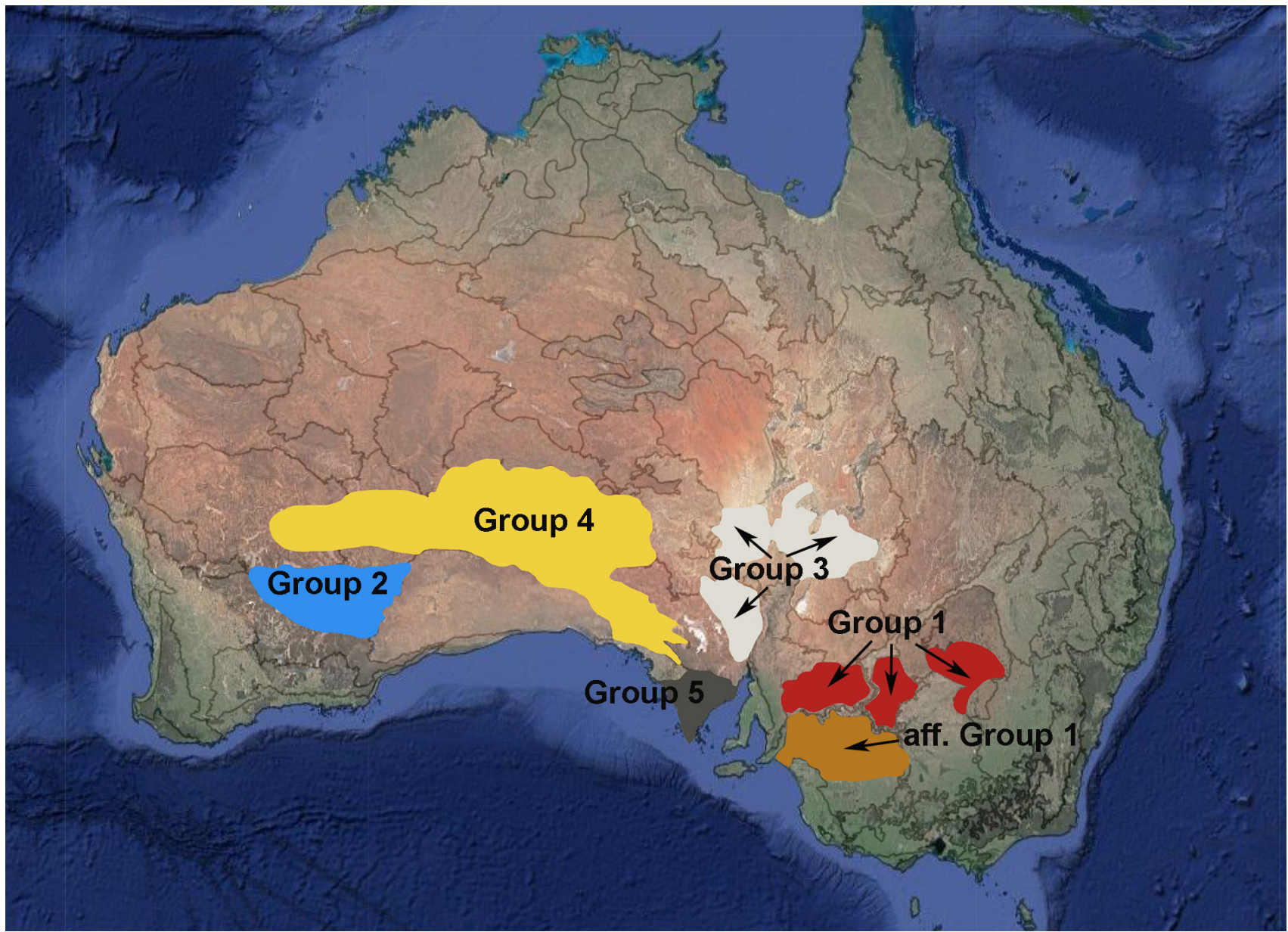

Figure 2. Generalized distribution of genetic groups identified in the phylogeny of populations formerly all included under Ctenophorus fordi, derived from a compilation of information from this study, the boundaries of clades identified by Edwards et al. (2015), and broad distribution data for specimen-based records in the Atlas of Living Australia (2019). The Group 1 genetic lineage (red) from central-west and southwest NSW, and adjacent areas of SA, representing $C$. spinodomus sp. nov. (=C. fordi Clade 4 of Edwards et al.); the Group $2 C$. fordi genetic lineage (blue) representing $C$. fordi s.s. from inland southwest WA, (=C.fordi of Edwards et al.); the Group 3 C. fordi genetic lineage (cream) from the desert dunefield systems of northwest NSW, southwest Qld., and central and northeast SA (=C. fordi Clade 3 of Edwards et al.); the Group 4 C. fordi genetic lineage (yellow) from the Great Victoria Desert of SA (=C. fordi Clade 1 of Edwards et al.); the Group 5 C. fordi genetic lineage (dark grey) from the Eyre Peninsula in SA (=C. fordi Clade 2 of Edwards et al.). Also shown is the distribution of populations referred to as aff. Group 1 (brown ochre colour) from south of the Murray River (=C. fordi Clade 5 of Edwards et al.) not included the genetic study but which on morphological criteria are considered related to Group 1 C. spinodomus sp. nov.

included samples from populations south of the Murray in northwest Victoria and far southeast SA which our genetic study did not include, and retrieved these as the sister to populations representing our Group 1 lineage, a relationship that was well-supported. However, these populations were included in our morphological study (see Fig. 3), and found to be similar to populations from our Group 1 lineage but with differences in several key morphological traits, lending support to a sister relationship between populations either side of the Murray River as broadly suggested by the genetic study of Edwards et al. (2015), which are here referred to as aff. Group 1.

Morphological study. Intra-lineage differentiation in morphology within the Group 1 genetic lineage: The populations in central-west and southwest NSW referable to the Group 1 genetic lineage appear to form two metapopulations largely disjunct in distribution, with only a few records from scattered populations in intervening areas. No differences in morphology were detected between samples from these metapopulations. Specimens from adjacent areas of southeast SA were not included in our genetic study, but no significant differences in morphology were detected between representatives of the populations from southeast SA and those from adjacent areas of southwest of NSW or those in central-west NSW. On this basis all of these populations are considered as conspecific.

Inter-lineage differentiation in morphology between the Group 1 genetic lineage and C. fordi genetic lineages: Populations referable to Group 1 genetic lineage from central-west/southwest NSW and populations from inland southeast SA are highly differentiated in morphology from other populations currently assigned to $C$. fordi. Differences in scalation and body proportions (refer to Table 2 and 3 for range, sd and sample size) distinguishing populations referable to the Group 1 genetic lineage from populations referable to the other $C$. fordi genetic lineages included: 
Table 1. Average net pairwise distances (below diagonal axis) and standard error (above diagonal axis) between major genetic lineage "Groups" for each of the mitochondrial genes sequenced and for these genes combined.

\begin{tabular}{lllllll}
\hline & $\begin{array}{c}\text { C. spinodomus } \\
\text { sp. nov. }\end{array}$ & C. fordi s.s. & $\begin{array}{c}\text { C. fordi } \\
\text { Strzelecki }\end{array}$ & $\begin{array}{c}\text { C. fordi } \\
\text { GVD }\end{array}$ & $\begin{array}{c}\text { C. fordi } \\
\text { Eyre }\end{array}$ & C. maculatus s.s. \\
\hline ND 4 & Group 1 & Group 2 & Group 3 & Group 4 & Group 5 & outgroup \\
Group 1 & & {$[0.011]$} & {$[0.012]$} & {$[0.014]$} & {$[0.010]$} & {$[0.012]$} \\
Group 2 & 0.090 & & {$[0.012]$} & {$[0.011]$} & {$[0.011]$} & {$[0.010]$} \\
Group 3 & 0.088 & 0.083 & & {$[0.015]$} & {$[0.010]$} & {$[0.013]$} \\
Group 4 & 0.109 & 0.082 & 0.107 & & {$[0.015]$} & {$[0.014]$} \\
Group 5 & 0.076 & 0.069 & 0.065 & 0.107 & & {$[0.010]$} \\
outgroup & 0.087 & 0.054 & 0.077 & 0.091 & 0.052 & \\
\hline 12S & Group 1 & Group 2 & Group 3 & Group 4 & Group 5 & outgroup \\
Group 1 & & {$[0.008]$} & {$[0.011]$} & {$[0.010]$} & {$[0.012]$} & {$[0.013]$} \\
Group 2 & 0.025 & & {$[0.010]$} & {$[0.007]$} & {$[0.010]$} & {$[0.012]$} \\
Group 3 & 0.035 & 0.036 & & {$[0.011]$} & {$[0.012]$} & {$[0.015]$} \\
Group 4 & 0.031 & 0.015 & 0.036 & & {$[0.012]$} & {$[0.014]$} \\
Group 5 & 0.043 & 0.037 & 0.044 & 0.044 & & {$[0.009]$} \\
outgroup & 0.049 & 0.043 & 0.054 & 0.050 & 0.027 & \\
\hline 16S & Group 1 & Group 2 & Group 3 & Group 4 & Group 5 & outgroup \\
Group 1 & & {$[0.005]$} & {$[0.005]$} & {$[0.006]$} & {$[0.007]$} & {$[0.007]$} \\
Group 2 & 0.014 & & {$[0.006]$} & {$[0.005]$} & {$[0.007]$} & {$[0.007]$} \\
Group 3 & 0.013 & 0.020 & & {$[0.007]$} & {$[0.006]$} & {$[0.006]$} \\
Group 4 & 0.016 & 0.016 & 0.024 & & {$[0.008]$} & {$[0.008]$} \\
Group 5 & 0.024 & 0.024 & 0.019 & 0.028 & & {$[0.008]$} \\
outgroup & 0.022 & 0.025 & 0.017 & 0.030 & 0.026 & \\
combined & Group 1 & Group 2 & Group 3 & Group 4 & Group 5 & outgroup \\
Group 1 & & {$[0.006]$} & {$[0.007]$} & {$[0.007]$} & {$[0.006]$} & {$[0.007]$} \\
Group 2 & 0.051 & 0.053 & {$[0.007]$} & {$[0.006]$} & {$[0.006]$} & {$[0.006]$} \\
Group 3 & 0.053 & $0.06067]$ & {$[0.006]$} & {$[0.008]$} \\
Group 4 & 0.062 & 0.046 & 0.065 & {$[0.007]$} & {$[0.007]$} & {$[0.005]$} \\
Group 5 & 0.052 & 0.048 & 0.046 & 0.068 & & \\
outgroup & 0.057 & 0.042 & 0.052 & 0.062 & 0.038 & \\
\hline
\end{tabular}

- from populations referable to aff. Group 1 from south of the Murray River in having: shorter hindlimbs in males** and on average fewer femoral pore scales in males ** (insufficient data for comparison of adult females).

- from populations referable to the $C$. fordi Group 2 genetic lineage (C. fordi s.s.) from inland southwest Western Australia in having; a significantly shorter tail in males* and females*; significantly shorter hindlimbs in males* and females*; a significantly longer body (AG) between fore and hindlimbs in males*; significantly fewer subdigital lamellae in males* and females*; significantly fewer upper labial scales in males* and females*; on average marginally more femoral pore scales in males**.

- from populations referable to the $C$. fordi Group 3 genetic lineage from the from the Strzelecki Desert system of northeast South Australia and adjacent northwest New South Wales in having; males being significantly smaller on average*, and females to a lesser extent**; in having a significantly shorter tail in males* and females*; significantly shorter hindlimbs in males* and females*; a significantly longer body (AG) between fore and hindlimbs in males*; significantly fewer subdigital lamellae in males* and females*; fewer upper labial scales in males** and significantly fewer in females*; significantly more femoral pore scales in males*.

- from populations referable to the C. fordi Group 4 genetic lineage from the Great Victoria Desert in having: a significantly shorter tail in males* and females*; significantly shorter hindlimbs in males* and females*; a significantly longer body (AG) between fore and hindlimbs in males*; significantly fewer upper labial scales in males* and females*; significantly fewer subdigital lamellae in males* and females*; significantly more femoral pore scales in males*.

- from populations referable to the C. fordi Group 5 genetic lineage Eyre Peninsula in South Australia in having: females being on average larger**; in having a marginally longer body $(\mathrm{AG})$ between fore and hindlimbs in males** and females**; significantly fewer subdigital lamellae in males*; significantly fewer femoral pore scales in males*. 


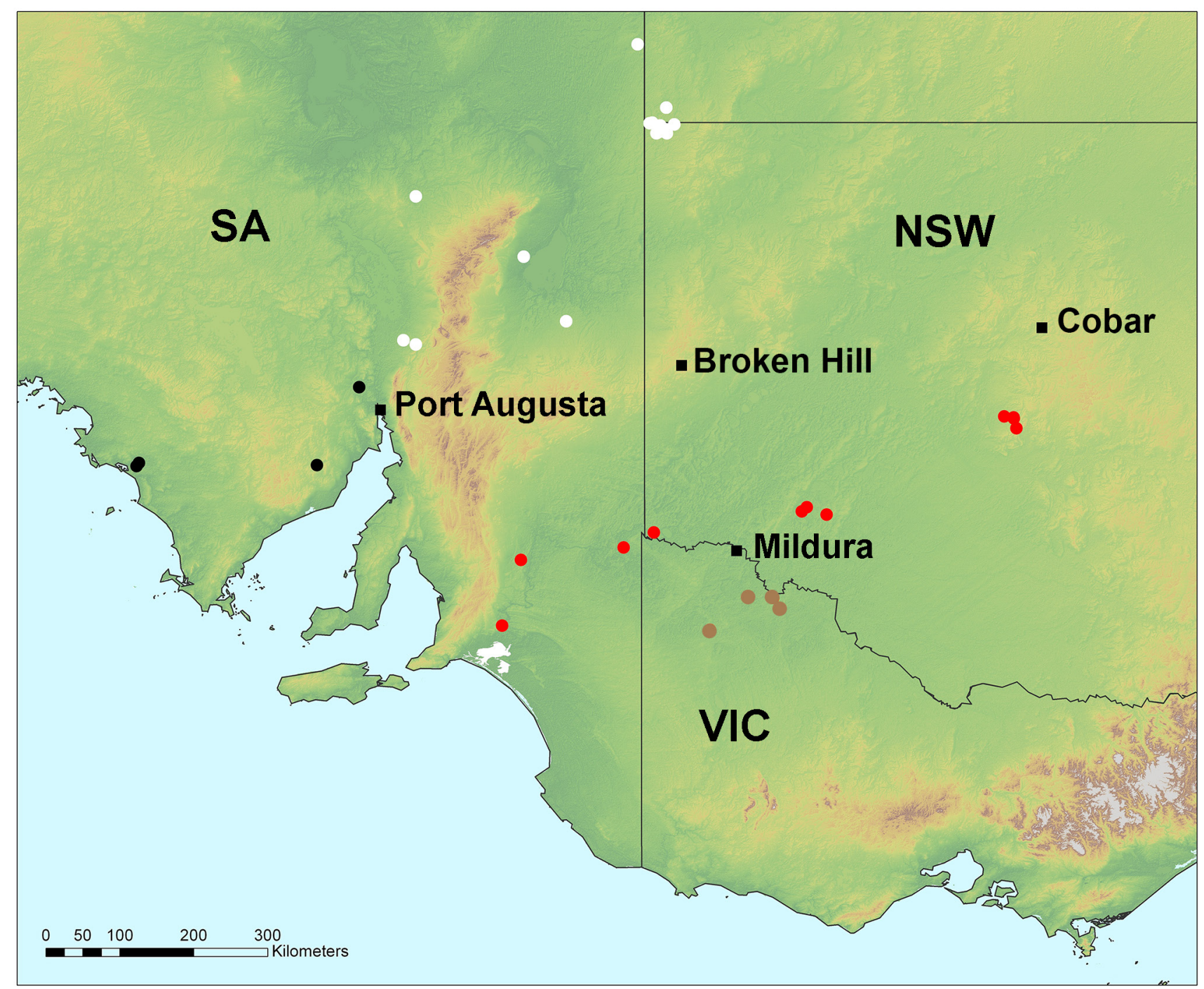

Figure 3. Distribution of specimens of Group 1 Ctenophorus spinodomus sp. nov. (red circles) used in morphological and genetic study relative to specimens of aff. Group 1 (brown ochre circles) from south of the Murray River used in the morphological study, and specimens of parapatric Group 3 C. fordi genetic lineage from the Strzelecki, Tarari and east Gawler dune systems (white circles) and Group 5 C. fordi genetic lineage from the Eyre Peninsula in SA (black circles).

Populations referable to the Group 1 genetic lineage (Fig. 4A) are markedly different in the expression of the dark throat and chest markings of adult males compared to populations referable to the other $C$. fordi group lineages (Fig. 4B-F), however, adult females lack these markings and cannot be readily distinguished from adult females referable to the other $C$. fordi genetic group lineages in coloration alone. The dark throat markings of Group 1 lineage adult males vary in distribution and intensity, but are usually present as obscure scattered spots and/or blotches, sometimes also tending to align either side of the midline, and only rarely forming well-defined narrow and elongate blotches which approach each other towards the chin. The dark throat markings of adult males referable aff. Group 1 (Fig. 4B) are similar in distribution to Group 1 lineage adult males but markedly more intense in colour. The throat markings of adult males referable to the $C$. fordi Group 2 (Fig. 4C) and Group 5 (Fig. $4 \mathrm{~F}$ ) genetic lineage examined were usually bold, black and coalescing to form an elongate blotch/es either side of the midline, whereas those of the $C$. fordi Group 3 and Group
4 genetic lineages (Fig. 4D, E) were typically obscure and poorly defined.

The dark chest markings of adult males referable to Group 1 genetic lineage are present variably as a few blotches medially between the forelimbs to being aligned to form a poorly defined T-shaped patch (Fig. 4A), with a narrow, occasionally broad the rearward extension. Adult aff. Group 1 males (Fig. 4B) have a similar T-shaped patch on the chest, but typically more intense in colour. The other geographically distinct genetic lineages within $C$. fordi typically have well developed dark chest patches which vary in shape and intensity, those of adult males examined referable to the C. fordi Group 2 (Fig. 4C) and Group 5 (Fig. 4F) genetic lineages being typically a bold, black, broadly cruciform "kite" shape (like the silhouette of a bird of prey), and those of adult males referable to the Group 3 (Fig. 4D) and Group 4 (Fig. 4E) genetic lineages also well-defined but with the pattern reduced in size.

The extent of regional differentiation in morphology, particularly that associated with throat and chest markings 


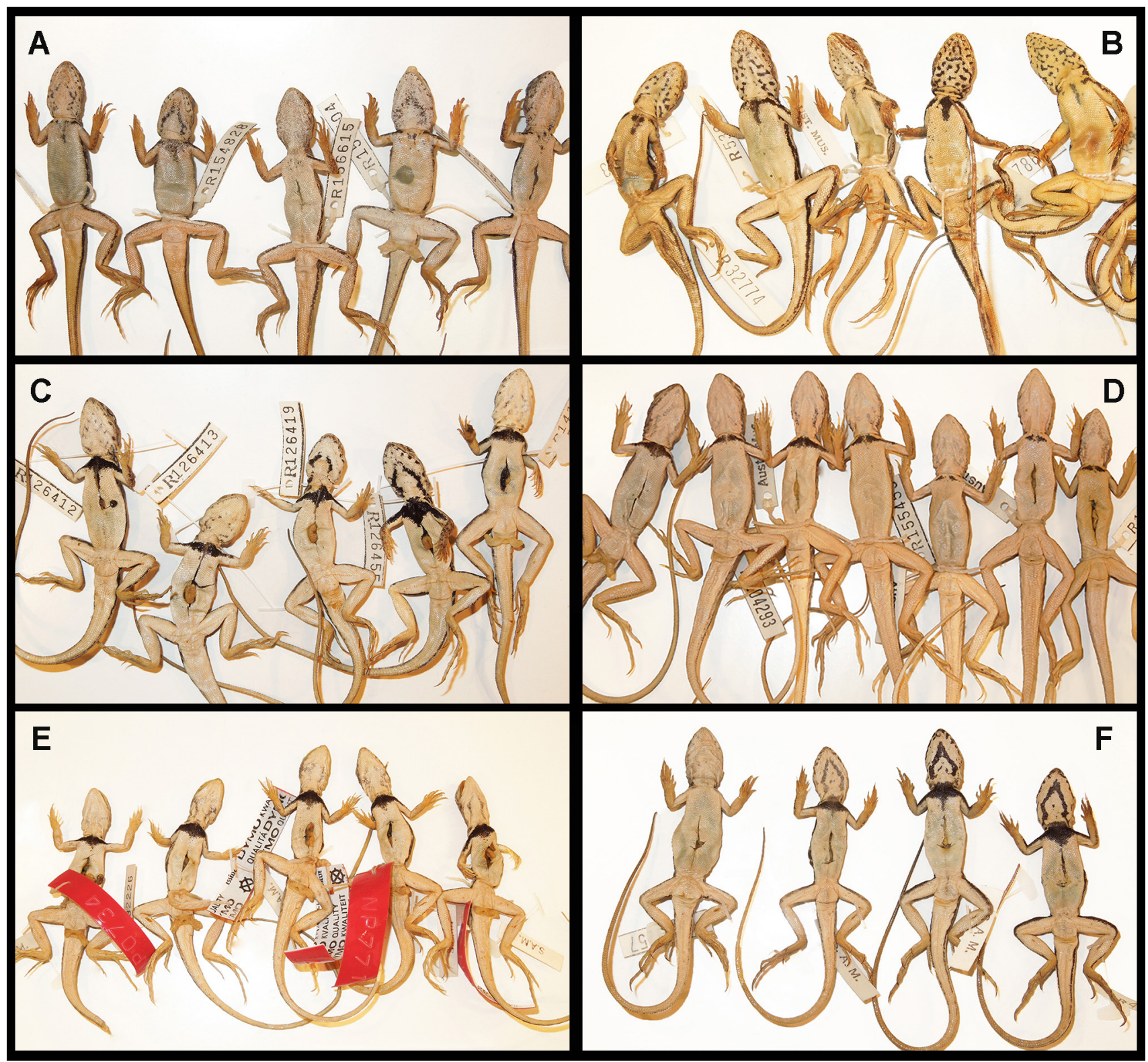

Figure 4. Comparison of dark ventral markings of adult males from groups formerly all included under Ctenophorus fordi: (A) Group 1 genetic lineage $C$. spinodomus sp. nov. from Yathong Nature reserve in central-west NSW; $(B)$ aff. Group 1 from south of the Murray River; $(C)$ the Group 2 C. fordi genetic lineage from Bonnie Vale in inland southwest WA; (D) the Group 3 C. fordi genetic lineage from Sturt National Park in the Strzelecki Desert system of northwest NSW; $(E)$ the Group 4 C. fordi genetic lineage from Hallinor Lake in the Great Victoria Desert of SA; $(F)$ the Group 5 C. fordi genetic lineage from near Kimba on the Eyre Peninsula in SA (photos C. Beatson).

in adult males, is consistent with the extent of geographically cohesive lineage differentiation identified by our genetic study, and with that published by Edwards et al. in 2015. That study regarded the species complex within which the genetic lineages of $C$. fordi reside as a group whose diversification is associated with the creation of new ecological niches in arid sand habits of southern Australia, initiated c. 3 million years ago (late Miocene). The extent of variation in the expression of throat and chest markings was interpreted as representing lineage specific visual signalling characters, with the evolution of these traits driven by interspecific interactions reinforcing boundaries between regionally distinct parapatric lineages in the arid zone where they contact. The highly divergent chest pattern of Group 1 adult males is consistent with its early divergence in the phylogeny presented here, and with that of Edwards et al., whereas the patterns of the Group 2-5 lineages are variations on a similar theme, a level of difference consistent with the more recent genetic divergence of these groups from each other.

\section{Taxonomy}

We here recognize populations from central-west and southwest NSW (our Group 1 lineage) and southeast SA as a highly differentiated, geographically defined evolutionary entity warranting recognition as a distinct species, described here as Ctenophorus spinodomus sp. nov. The population from south of the main Murray River channel in northwest Victoria and adjacent areas of southeast SA is similar in a number of aspects of morphology to populations from central 
and southwest NSW and southeast SA north of the Murray River, but differs in several key morphological traits, and was identified as a distinct but related genetic lineage by Edwards et al. (2015). At this time, we recognize it as related to, but distinct from, $C$. spinodomus sp. nov., and refer to it as $C$. aff. spinodomus pending a more comprehensive investigation of these populations.

Our investigations also found significant genetic and morphological differentiation between the geographically cohesive groups of populations remaining under $C$. fordi. Our description of $C$. spinodomus sp. nov. below provides distinguishing characteristics between it and each of these geographic lineages, but the formal taxonomic treatment of these is part of a work in progress by Edwards and Hutchinson that also includes related taxa currently under C. maculatus.

\section{Agamidae Gray, 1827}

Ctenophorus Fitzinger, 1843

\section{Ctenophorus spinodomus sp. nov. Sadlier, Colgan, Beatson \& Cogger}

http://zoobank.org/NomenclaturalActs/47B3F6FF-A157-4C41-8070-FFE53FD36EDF

\section{Figs 5-7}

Holotype. AMS R.156615, Yathong Nature Reserve $\left(32.5742^{\circ} \mathrm{S} 145.3828^{\circ} \mathrm{E}\right) \mathrm{NSW}, \mathrm{G}$. Swan (07 October 1999). Paratypes. AMS R.154827-28, Yathong Nature Reserve $\left(32.5742^{\circ} \mathrm{S} 145.3828^{\circ} \mathrm{E}\right)$, NSW, G. Swan (12-14 October 1999); R.156647, R.156711, Yathong National Park (32.5869 $\left.{ }^{\circ} \mathrm{S} 145.4975^{\circ} \mathrm{E}\right), \mathrm{NSW}, \mathrm{G}$. Swan (1999); R.156704, Yathong National Park or Yarra Property $\left(32.58^{\circ} \mathrm{S} 145.40^{\circ} \mathrm{E}\right), \mathrm{NSW}, \mathrm{G}$. Swan (1999); R.157315, Yathong Nature Reserve, $10 \mathrm{~km}$ NNW of Shearers Quarters $\left(32.5864^{\circ} \mathrm{S} 145.4972^{\circ} \mathrm{E}\right), \mathrm{NSW}, \mathrm{P}$. Harlow and G. Swan (07 November 1998); R.145176-77, R.145179, Yathong Nature Reserve (32.72 $\left.{ }^{\circ} \mathrm{S} 145.53^{\circ} \mathrm{E}\right)$, NSW, P. Harlow; R.114208-09, R.114211, R.114213-15, Mungo National Park, 5.0 km N of SE corner $\left(33.77^{\circ} \mathrm{S} 143.22^{\circ} \mathrm{E}\right)$, NSW, R. Sadlier and G. Shea (02 November 1984); R.114456-57, Mungo National Park, $5.0 \mathrm{~km} \mathrm{~N}$ of SE corner $\left(33.77^{\circ} \mathrm{S} 143.22^{\circ} \mathrm{E}\right)$, NSW, R. Sadlier and G. Shea (12 November 1984); R.114347-48, R.114349, Top Hut Homestead, $6.9 \mathrm{~km} \mathrm{~S}$ on Old Arumpo Rd. $\left(33.73^{\circ} \mathrm{S} 142.92^{\circ} \mathrm{E}\right)$, NSW, R. Sadlier and G. Shea (17 November 1984); R.115216, Top Hut Station, 8 km NE Roys Tank (33.68 $\left.{ }^{\circ} \mathrm{S} 142.98^{\circ} \mathrm{E}\right)$, NSW, C. Tiedermann (25 November 1984); R.153214-16, Warrakoo Station $\left(33.9858^{\circ} \mathrm{S} 141.1180^{\circ} \mathrm{E}\right), \mathrm{NSW}, \mathrm{M}$. LeBreton (16 October 1998); R.7755-76, Murray Bridge (35.12 $\left.{ }^{\circ} \mathrm{S} 139.27^{\circ} \mathrm{E}\right), \mathrm{SA}$; R.20989, Renmark (34.17 S $\left.140.75^{\circ} \mathrm{E}\right), \mathrm{SA}$; R.145481-82 Brookfield Conservation Park $\left(34.32^{\circ} \mathrm{S} 139.50^{\circ} \mathrm{E}\right), \mathrm{SA}$; R.104842-43, Renmark (34.17 S $\left.140.75^{\circ} \mathrm{E}\right)$, SA.

Etymology. The species epithet is derived from a combination of the Latin spinosus for spiny and domus for home, in reference to the species' reliance on Triodia grass hummocks.

The common name Mallee Dragon has been applied to "Ctenophorus fordi" in its broadest sense, in keeping with this concept we recommend the common name Eastern Mallee Dragon for the species described here as Ctenophorus spinodomus sp. nov.
Diagnosis. Ctenophorus spinodomus sp. nov. is diagnosed from all other species in the genus, except for the taxa currently contained within $C$. maculatus and $C$. fordi, in having a near continuous row of femoral pores either side (15-22) in adult males arranged in a row that arches forward to an apex on the midline, and a dark chest patch (although obscure) between the forelimbs in adult males. Adult female C. spinodomus sp. nov. can be distinguished from other regionally sympatric (C. pictus) or parapatric (C. nuchalis) species of Ctenophorus by the presence (vs absence) of a fine, typically uninterrupted pale dorsolateral stripe down the body from the neck to just past the hindlimbs.

Adult male $C$. spinodomus sp. nov. are diagnosed from all named subspecies of Ctenophorus maculatus in having fewer femoral pores in total (maximum 41 vs range of 40-57 encompassed by the maculatus subspecies-Storr, 1965), and in the dark markings on the throat being present as a series of dark spots and blotches either side of the midline of varying intensity and degree of coalescence vs a pattern of well-defined narrow to broad dark bars either side.

The following features of colouration and scalation in combination distinguish Ctenophorus spinodomus sp. nov. from taxa assignable to the other genetic lineages under $C$. fordi (see Tables 2 and 3): tail length c. 2.1-2.4 times the body length in males and c. 1.95-2.15 times in females: hindlimb length c. $82-93 \%$ SVL in males, c. $74-93 \%$ in females; upper labial scales 10-13; subdigital lamellae scales 25-31; femoral pore scales in males 16-22 either side; dark markings of the throat of adult males typically obscure and present as scattered spots and blotches, occasionally aligned either side of the midline but not coalescing to form elongate blotches; chest of adult males with a typically poorly-defined black "T" shaped patch.

Comparison with other species (Tables 2 and 3): Adult male $C$. spinodomus sp. nov. are most similar to adult male aff. Group 1 (C. aff. spinodomus), but differ in having shorter limbs and fewer preanal pores. Adult male and female $C$. spinodomus sp. nov. have a shorter tail length on average than adult males and females from other populations referable to the $C$. fordi Group 2 (C. fordi s.s.), Group 3 (Strzelecki) and Group 4 (GVD) genetic lineages, but with overlap in ranges. The tail length of adult male $C$. spinodomus sp. nov. is similar to adult males referable to the $C$. fordi Group 5 (Eyre) genetic lineage, but adult female $C$. spinodomus sp. nov. have a significantly shorter tail than Group 5 females with only minimal overlap in range. The average hindlimb length of adult male and female $C$. spinodomus sp. nov. is shorter than Group 2, Group 3 and Group 4 males and females but with overlap in ranges, though minimal to negligible respectively with Group 4 males and females. In scalation adult male and female $C$. spinodomus sp. nov. have on average fewer subdigital lamellae than adult Group 2, Group 3 and Group 4 males and females but with overlap in ranges, though minimal with respect to Group 3 females and negligible with respect to Group 4 males and females, and adult male $C$. spinodomus sp. nov. have fewer subdigital lamellae than Group 5 adult males but with overlap in range. Adult male $C$. spinodomus sp. nov. have on average more femoral pore scales than Group 3 and Group 4 males with minimal to negligible overlap respectively in range, and less than Group 5 males with minimal overlap in range.

Adult male $C$. spinodomus sp. nov. have a black "T" 


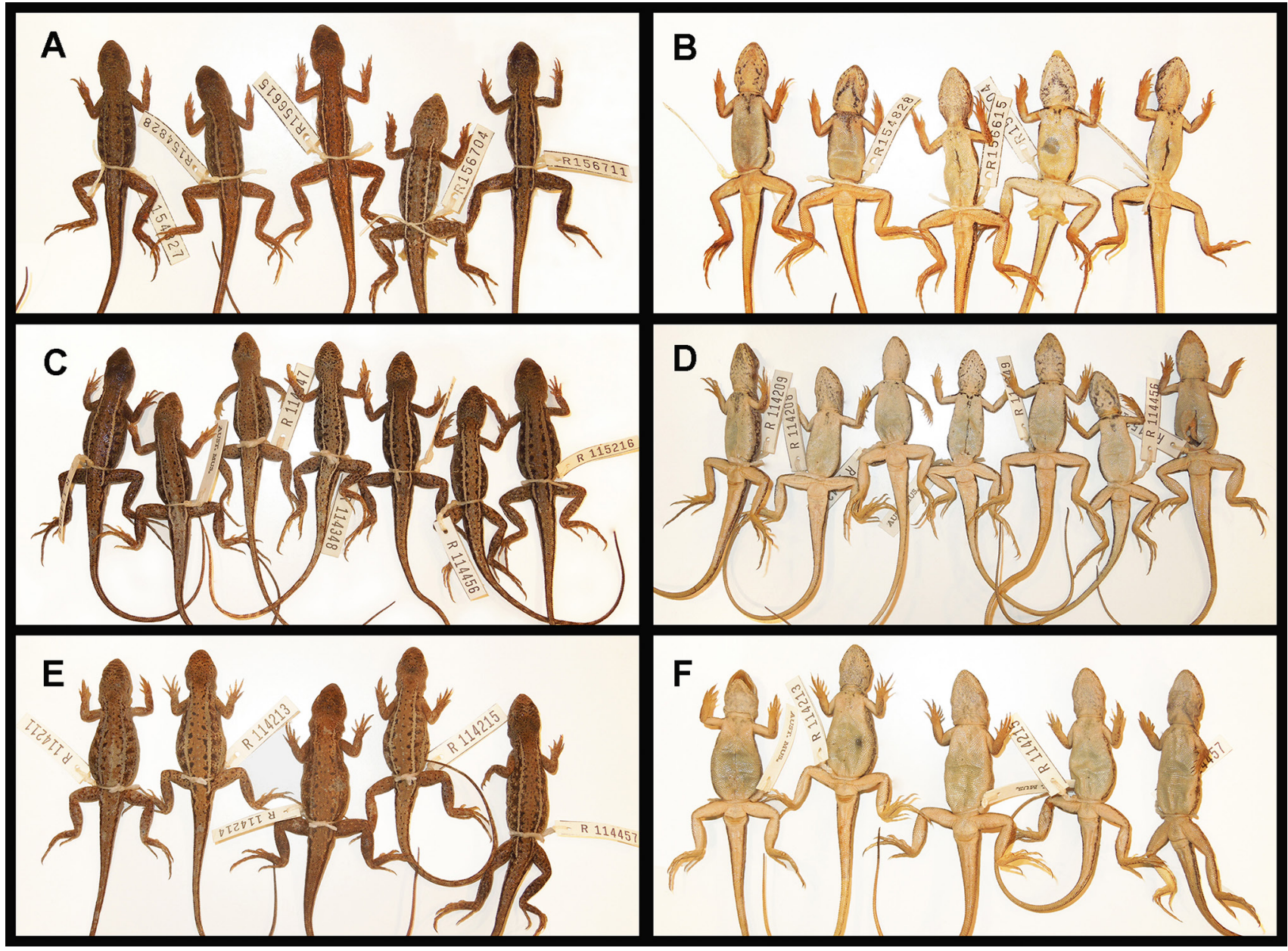

Figure 5. Types of Ctenophorus spinodomus sp. nov. adult males from Yathong Nature Reserve in central-west NSW ( $A$, $B$ ), including holotype AMS R.156615 (middle specimen), and representative adult males $(C, D)$ and females $(E, F)$ from Mungo National Park in southwest NSW (photos C. Beatson).

shaped chest patch which is typically poorly defined. The black chest markings of aff. Group 1 and taxa assignable to the other genetic lineages under C. fordi are typically bold in expression and differ markedly in shape.

Description. The species is described from 17 adult males and 15 adult females regarded as representative of populations in central-west and southwest New South Wales, and southeast South Australia.

Measurements and scalation adult males: size 41.4-48.7 $\mathrm{mm} \mathrm{SVL}$ (mean $=45.2$ ); distance from axilla to groin 44.0 $52.7 \%$ SVL (mean $=47.3$ ); head length (HDL) $20.8-25.8 \%$ SVL $($ mean $=23.9)$; head width 75.4-93.4\% HDL (mean = 83.9); hindlimb length (HLL) 82.1-92.6\% SVL (mean = 87.3); tail length $207.1-241.5 \% \mathrm{SVL}($ mean $=224.1, \mathrm{n}=16)$; upper labial scales $10-13($ mean $=12.0, \mathrm{sd}=0.7)$; lamellae beneath fourth toe $25-30$ (mean $=27.8, \mathrm{sd}=1.8)$; femoral pore scales $16-22($ mean $=18.6, \mathrm{sd}=1.42, \mathrm{n}=15)$.

Measurements and scalation adult females: size 43.6-54.5 mm SVL ( $m e a n=48.6)$; distance from axilla to groin 43.9$53.6 \%$ SVL (mean = 48.1); head length (HDL) 20.8-25.4\% SVL $($ mean $=23.4)$; head width $80.3-92.7 \%$ HDL (mean $=85.0$ ); hindlimb length (HLL) $74.5-91.7 \%$ SVL $($ mean $=$ 82.0); tail length $193.5-216.3 \%$ SVL ( mean $=205.2$ ); upper labial scales $10-13($ mean $=11.9, \mathrm{sd}=0.7)$; lamellae beneath fourth toe 25-31 (mean $=27.5, \mathrm{sd}=1.5)$.
Significant differences between adult males and adult females were found for body size* with adult females larger on average than adult males (SVL mean $=48.6$ vs 45.2 ), for tail length* with adult males having longer tails (TL mean $=224.1$ vs $205.2 \%$ SVL), and for hindlimb length* with adult males having longer limbs (HLL mean $=87.3 \mathrm{vs}$ $82.0 \% \mathrm{SVL}$ ).

Colour and pattern: adult males (Figs 5A-D, 6A, 7A) dorsal surface in life orange-brown and defined from the lateral surface by a narrow (2 sometimes 3 scales width), pale, dorsolateral stripe with a dark edge that extends from the nape to base of the tail ending abruptly just past the hindlimbs. Dorsal surface of the body with a series of small dark blotches adjacent to and contacting the pale dorsolateral stripe and a scattering of very fine dark flecks on the top of head and body, the extent of spotting (particularly on the head) varying from sparse to moderately dense between individuals at a location. Intrapopulation variation in definition of pattern on the lateral surface is present. Upperlateral surface with a base colour similar (orange-brown) or marginally darker (mid brown) in tone to the dorsal surface, and dominated by a series of large dark markings (blackish blotches) of varying intensity and definition between the fore and hindlimbs, usually concordant in placement with the position of opposing small dark blotches on the dorsal surface of the body. Mid-lateral surface with a variably 

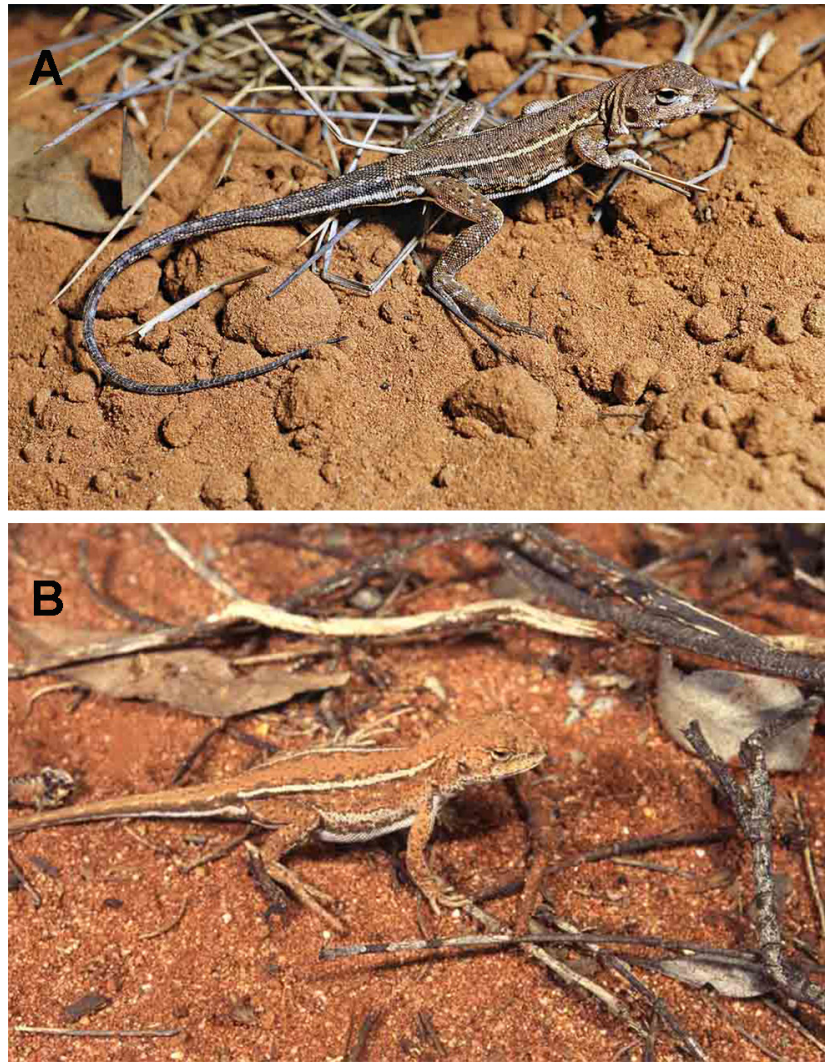

Figure 6. Live adult male $(A)$ and female (B) Ctenophorus spinodomus sp. nov. from Round Hill Nature Reserve in central-west NSW (photos H. Cogger).

defined pale midlateral stripe along the side of the body between the fore and hindlimbs, distinct and defined by the dark markings (blotches) of the upper-lateral surface and a line of fine dark scattered spots along the upper and lower edges of the pale stripe, less well-defined in other individuals where the line of dark makings along the upper and lower edges of this stripe are not continuous and present only as scattered flecks. Lower surface with similar colouration to upper-lateral surface, but with the base colour tending to border the lower edge of the pale midlateral stripe and the darker markings the lateroventral margin. Tail similar in colour above to the dorsal surface of the body. The pale dorsolateral stripe of the body continues a third or less of the way along the tail as a series of faint pale spots scattered along the dorsolateral edge. Side of tail uppermost dark (an extension of the dark upper lateral markings of the body) and tending to form a distinct stripe, which in turn is bordered below by a pale stripe (an extension of the pale midlateral stripe of the body) for approximately the basal third of the tail, which in turn is defined for most of its length from the underside of the tail by a series of fine dark markings along the ventrolateral margin, usually continuous along most of its length and forming a fine dark stripe.

Ventral surface pale, white in life, with dark scattered markings on the throat and chest. Dark throat markings variable in distribution and intensity, sometimes sparse and scattered but also tending to align either side of the midline, and only rarely forming narrow and elongate blotches which approach each other towards the chin. Dark chest markings also variable in distribution and intensity, sometimes presents as a few blotches medially between the forelimbs through to being aligned to form a poorly defined " $T$ "-shaped patch with the lateral extensions typically narrow but the rearward extension varying from narrow to occasionally broad. Most individuals with a narrow alignment of dark markings along the anterior ventrolateral edge of the forelimbs, sometimes present as a continuous stripe at least on the humerus.

Adult females (Figs 5E-F, 6B, 7B)-dorsal and lateral surface with a similar pattern to males but overall lighter in tone. Ventral surface with the dark throat markings present as greyish specks and smudges, and chest typically without areas of dark markings.

Variation. No significant difference in scalation or body proportions were detected between populations from centralwest NSW and those from southwest NSW, or with those from southeast SA west of the Murray River.

Distribution and biology. Ctenophorus spinodomus sp. nov. occurs on the red sandplains belonging to the Mallee dunefields (as identified by Hesse, 2010) of central-west and southwest NSW and adjacent areas of inland southeast SA that lie to the north and west of the main Murray River channel, within the IBRA bioregions of the Murray-Darling Depression (with the exception of the Darling Depression subregion) and Cobar Peneplain bioregions. Here, the distribution of populations in central-west and southwest NSW is dependent on the presence of Triodia hummock grass which grows as a groundcover in association with mallee woodlands (Cogger, 1974; Sadlier \& Shea, 1989), termed Triodia Mallee habitat (Fig. 8). Extensive information on the species biology has been published by Cogger $(1974,1978)$ based on population studies undertaken at Round Hill Nature Reserve in centralwest NSW. We present here a summary of points relevant to its reliance upon this habitat type and vulnerability to decline. The population referred to as $C$. aff. spinodomus occurs in adjacent areas of northwest Victoria to the south and east of

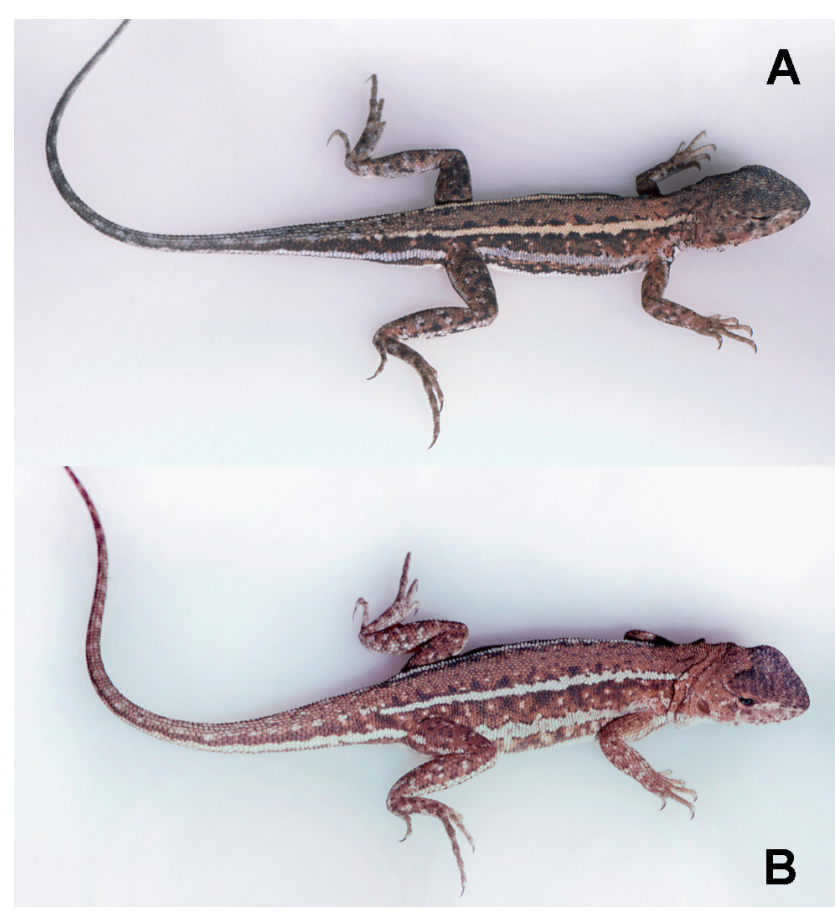

Figure 7. Live adult male (A) and female (B) Ctenophorus spinodomus sp. nov. from Mungo National Park in southwest NSW (photos R. Sadlier). 
Table 2. Measurements and scalation values of adult males examined from populations assignable to the major "Groups".

\begin{tabular}{lllllll}
\hline & $\begin{array}{c}\text { Group 1 } \\
\text { spinodomus } \\
\text { sp. nov. }\end{array}$ & $\begin{array}{c}\text { aff. Group 1 } \\
\text { aff. spinodomus }\end{array}$ & $\begin{array}{l}\text { Group 2 } \\
\text { fordi } \text { s.s. }\end{array}$ & $\begin{array}{c}\text { Group 3 } \\
\text { fordi } \\
\text { Strzelecki }\end{array}$ & $\begin{array}{l}\text { Group 4 } \\
\text { fordi } \\
\text { GVD }\end{array}$ & $\begin{array}{l}\text { Group 5 } \\
\text { fordi } \\
\text { Eyre }\end{array}$ \\
\hline SVL range & $41.4-48.7$ & $43.7-50.6$ & $42.2-51.1$ & $42.4-55.3$ & $40.3-53.7$ & $42.2-49.7$ \\
mean \pm sd & $45.2 \pm 2.24$ & $47.4 \pm 2.8$ & $47.2 \pm 2.5$ & $49.5 \pm 3.3$ & $48.4 \pm 3.1$ & $46.4 \pm 2.9$ \\
n & 17 & 7 & 13 & 23 & 18 & 6 \\
TL range & $207.1-241.5$ & $203.8-235.4$ & $231.6-262.2$ & $243.2-294.8$ & $217.6-291.0$ & $196.0-243.5$ \\
mean \pm sd & $224.1 \pm 8.4$ & $224.2 \pm 11.7$ & $243.7 \pm 10.1$ & $268.9 \pm 12.3$ & $257.9 \pm 20.6$ & $221.5 \pm 16.0$ \\
n & 16 & 6 & 11 & 21 & 18 & 6 \\
AG range & $44.0-52.7$ & $39.5-48.0$ & $39.2-47.0$ & $39.2-48.6$ & $38.7-47.4$ & $42.7-46.7$ \\
mean \pm sd & $47.3 \pm 2.3$ & $45.4 \pm 2.8$ & $43.4 \pm 2.8$ & $44.1 \pm 2.6$ & $43.1 \pm 2.5$ & $44.8 \pm 1.5$ \\
n & 17 & 7 & 13 & 23 & 18 & 6 \\
HDL range & $20.8-25.8$ & $23.5-26.1$ & $21.6-25.4$ & $21.0-25.3$ & $21.4-26.4$ & $23.5-25.5$ \\
mean \pm sd & $23.9 \pm 1.3$ & $24.7 \pm 1.0$ & $23.8 \pm 1.2$ & $23.3 \pm 1.1$ & $23.4 \pm 1.4$ & $24.4 \pm 0.9$ \\
n & 17 & 7 & 13 & 23 & 18 & 6 \\
HDW range & $75.4-93.4$ & $72.3-85.8$ & $78.2-92.1$ & $77.2-87.1$ & $73.4-89.3$ & $78.6-89.5$ \\
mean \pm sd & $83.9 \pm 4.7$ & $80.8 \pm 4.6$ & $85.0 \pm 3.7$ & $81.6 \pm 2.7$ & $82.2 \pm 4.0$ & $84.1 \pm 3.9$ \\
n & 17 & 7 & 13 & 23 & 18 & 6 \\
HLL range & $82.1-92.6$ & $89.0-95.5$ & $85.1-98.9$ & $77.8-101.4$ & $90.4-108.5$ & $84.5-92.4$ \\
mean \pm sd & $87.3 \pm 2.9$ & $91.7 \pm 2.2$ & $92.9 \pm 3.5$ & $94.7 \pm 4.8$ & $98.2 \pm 4.7$ & $89.2 \pm 3.6$ \\
n & 17 & 7 & 13 & 23 & 17 & 6 \\
SDL range & $25-30$ & $25-32$ & $28-36$ & $27-37$ & $31-37$ & $29-34$ \\
mean \pm sd & $27.7 \pm 1.8$ & $28.0 \pm 2.3$ & $32.5 \pm 2.4$ & $33.6 \pm 2.3$ & $33.9 \pm 1.5$ & $31.2 \pm 1.7$ \\
n & 17 & 7 & 13 & 23 & 18 & 6 \\
ULS range & $10-13$ & $11-13$ & $12-15$ & $11-15$ & $12-16$ & $12-14$ \\
mean \pm sd & $12.0 \pm 0.7$ & $12.2 \pm 0.7$ & $13.4 \pm 0.8$ & $12.8 \pm 0.9$ & $13.5 \pm 1.1$ & $12.8 \pm 0.4$ \\
n & 17 & 7 & 13 & 23 & 18 & 6 \\
FPS range & $16-22$ & $19-23$ & $18-21$ & $10-18$ & $12-16$ & $20-23$ \\
mean \pm sd & $18.6 \pm 1.4$ & $20.7 \pm 1.3$ & $17.2 \pm 2.1$ & $14.5 \pm 1.9$ & $14.2 \pm 1.1$ & $21.2 \pm 1.2$ \\
n & 15 & 7 & 12 & 23 & 18 & 6 \\
\hline
\end{tabular}

the main Murray River channel within the Mallee dunefields, and the extent of reliance of these populations on Triodia Mallee habitat has yet to be established.

Ctenophorus spinodomus sp. nov. has an essentially annual life cycle, with some individuals extending into a second, rarely a third, season. Marked mortality of adults begins in late December and extends into January, with a loss of up to $85 \%$ of the population. Densities approaching 125 individuals per hectare have been found in areas regenerated 5-10 years after fire, but climax mallee communities with well-developed Triodia have lower densities. Males have a larger home range (mean $0.032 \mathrm{ha}$ ) than females (mean 0.015 ha), with juveniles a smaller range ( $0.007 \mathrm{ha}$ ) than adults, but with little shift in home range and negligible migration, and no territorial behaviour has been recorded (Cogger, 1978).

The species diel cycle revolves around utilization of Triodia clumps at various times of the day. During the night individuals shelter within Triodia and undergo preemergence basking amongst the spines of the clump to attain a body temperature sufficient for activity. On emergence individuals have not been observed active more than a few metres from the nearest clump of Triodia. During the hottest part of the day most lizards retire within the clumps of Triodia where summer humidity levels are higher than ambient and temperature during the hottest part of the day markedly lower than ambient and more so than substrate. However, during the winter period few individuals were found residing inactive within Triodia, rather, opportunistic observations suggest they dig into soil and shelter underground, but not in specially constructed burrows. It feeds almost exclusively on small ants but will take other insects opportunistically.

The earliest recorded egg-laying in Round Hill was midOctober and the latest in late January, with a peak period for egg deposition around mid-November. Development of a clutch of eggs takes less than 8 weeks. Females deposit 2-3 eggs in a chamber that is constructed and sealed on the same day after laying. No female was recorded laying more than two clutches in a season, but given the clutch development period and length of laying season three clutches could be achieved. On average only $20 \%$ of hatchlings survive to reproductive age in the Round Hill population.

Comments. Wells \& Wellington described Phthanodon hawkeswoodi sp. nov. in 1985. The designated holotype is a specimen (AMS R.116983) from Glenlea central fire trail Yathong Nature Reserve, NSW (collector A. B. Rose and J. Brickhill, 14 March 1981). The diagnosis presented by Wells \& Wellington amounts to an extended description of the holotype that failed to provide either a "... definition that states in words characters that are purported to differentiate the taxon" or a "... bibliographic reference to such a published statement...", as required under Article 13(a)(i-ii) of the Third edition of the Code of Zoological Nomenclature applicable at that time. As such, the description of Phthanodon hawkeswoodi Wells \& Wellington, 1985 is unavailable for application to the species described here as C. spinodomus sp. nov.

Houston (1978) identified three distinct races of what was then considered Amphibolurus fordi in SA. One of these, his "eastern" race, was mapped as being from far southeast 
Table 3. Measurements and scalation values of adult females examined from populations assignable to the major "Groups".

\begin{tabular}{lllllll}
\hline & $\begin{array}{c}\text { Group 1 } \\
\text { spinodomus } \\
\text { sp. nov. }\end{array}$ & $\begin{array}{c}\text { aff. Group 1 } \\
\text { aff. spinodomus }\end{array}$ & $\begin{array}{l}\text { Group 2 } \\
\text { fordi s.s. }\end{array}$ & $\begin{array}{c}\text { Group 3 } \\
\text { fordi } \\
\text { Strzelecki }\end{array}$ & $\begin{array}{c}\text { Group 4 } \\
\text { fordi } \\
\text { GVD }\end{array}$ & $\begin{array}{c}\text { Group 5 } \\
\text { fordi } \\
\text { Eyre }\end{array}$ \\
\hline SVL range & $43.6-54.5$ & $46.6-48.3$ & $41.2-53.5$ & $41.6-58.4$ & $43.7-55.1$ & $36.0-49.1$ \\
mean \pm sd & $48.6 \pm 2.8$ & $47.4 \pm 1.2$ & $47.4 \pm 3.6$ & $52.3 \pm 4.3$ & $48.2 \pm 3.8$ & $41.5 \pm 6.1$ \\
n & 15 & 2 & 14 & 16 & 13 & 4 \\
TL range & $193.5-216.3$ & $203.9-217.4$ & $210.4-243.9$ & $235.6-272.7$ & $233.4-255.9$ & $208.3-231.5$ \\
mean \pm sd & $205.2 \pm 8.0$ & $205.2 \pm 9.6$ & $225.2 \pm 10.8$ & $249.5 \pm 11.1$ & $245.9 \pm 5.9$ & $216.1 \pm 13.4$ \\
n & 13 & 2 & 11 & 15 & 10 & 3 \\
AG range & $43.9-53.6$ & $47.8-49.1$ & $41.3-51.6$ & $39.7-54.6$ & $43.2-56.1$ & $41.9-47.3$ \\
mean \pm sd & $48.1 \pm 2.4$ & $48.5 \pm 0.9$ & $45.9 \pm 3.3$ & $47.6 \pm 4.2$ & $48.3 \pm 3.5$ & $45.3 \pm 2.3$ \\
n & 15 & 2 & 14 & 16 & 13 & 4 \\
HDL range & $20.8-25.4$ & $23.4-23.6$ & $21.9-26.2$ & $20.3-26.2$ & $21.4-25.5$ & $24.2-26.2$ \\
mean \pm sd & $23.4 \pm 1.4$ & $23.5 \pm 0.1$ & $23.6 \pm 1.2$ & $22.4 \pm 1.4$ & $23.3 \pm 1.2$ & $25.4 \pm 0.9$ \\
n & 15 & 2 & 14 & 16 & 13 & 4 \\
HDW range & $80.3-92.7$ & $85.3-88.6$ & $79.5-94.1$ & $78.9-91.2$ & $78.4-89.0$ & $81.0-86.7$ \\
mean \pm sd & $85.0 \pm 3.8$ & $87.0 \pm 2.3$ & $87.0 \pm 4.4$ & $84.2 \pm 3.3$ & $83.3 \pm 3.3$ & $84.5 \pm 2.6$ \\
n & 15 & 2 & 14 & 16 & 13 & 4 \\
HLL range & $74.5-91.7$ & $80.7-81.5$ & $84.6-99.5$ & $82.7-101.2$ & $91.9-101.8$ & $82.2-88.9$ \\
mean \pm sd & $82.0 \pm 4.6$ & $81.1 \pm 0.6$ & $90.4 \pm 4.0$ & $91.2 \pm 5.5$ & $96.6 \pm 3.4$ & $86.4 \pm 3.0$ \\
n & 15 & 2 & 14 & 16 & 13 & 4 \\
SDL range & $25-31$ & $27-29$ & $28-34$ & $31-38$ & $31-38$ & $26-28$ \\
mean \pm sd & $27.5 \pm 1.5$ & $28 \pm 1.4$ & $32.1 \pm 1.7$ & $34.0 \pm 1.8$ & $33.8 \pm 2.4$ & $27.5 \pm 1.0$ \\
n & 15 & 2 & 14 & 16 & 13 & 4 \\
ULS range & $10-13$ & $11-14$ & $11-15$ & $11-15$ & $13-15$ & $11-13$ \\
mean \pm sd & $11.9 \pm 0.7$ & $12.5 \pm 1.4$ & $13.4 \pm 1.2$ & $12.9 \pm 0.8$ & $13.6 \pm 0.5$ & $12.1 \pm 0.6$ \\
n & 15 & 2 & 14 & 16 & 13 & 4 \\
\hline
\end{tabular}

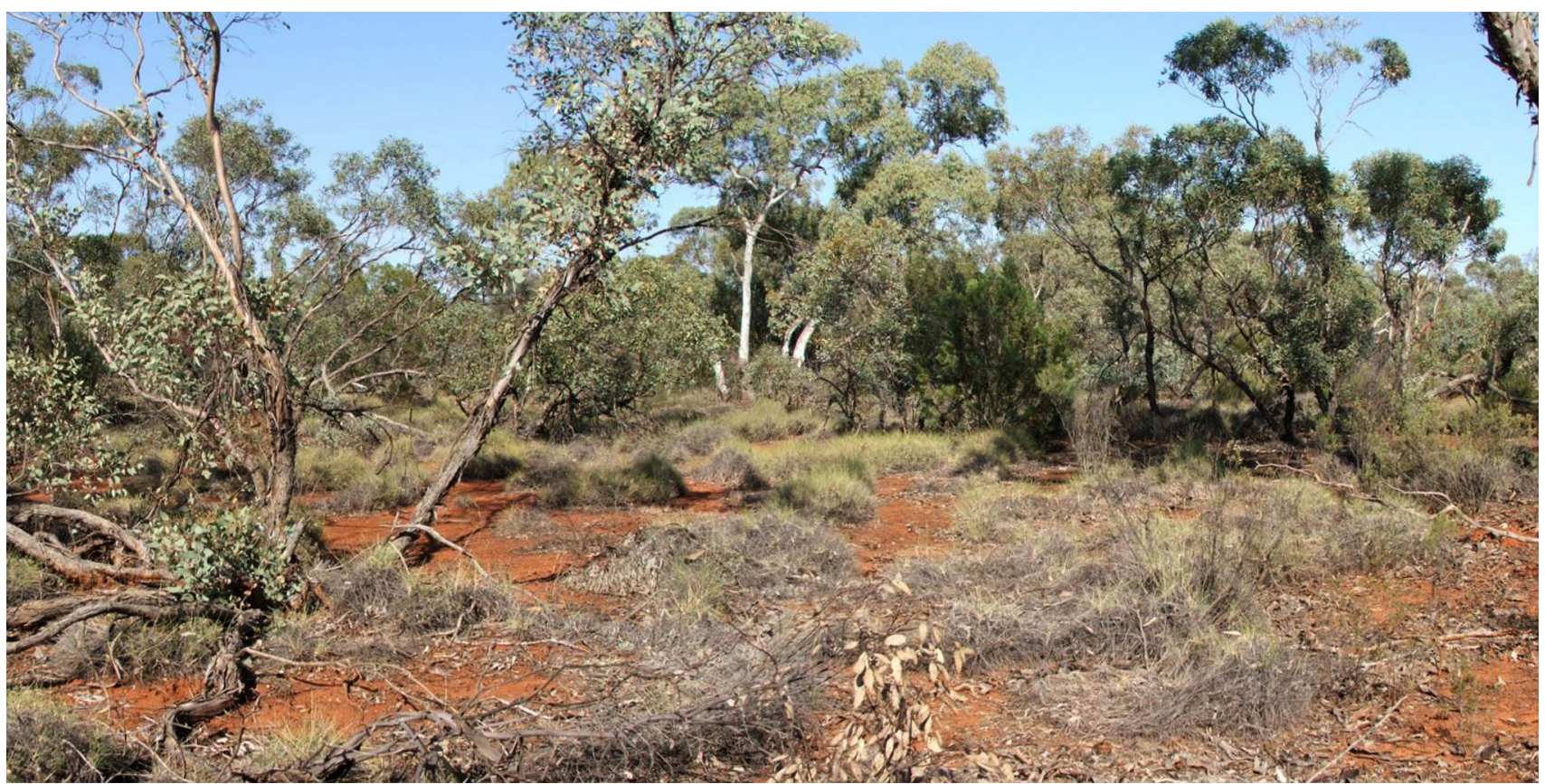

Figure 8. Triodia Mallee habitat_-Triodia hummock grass groundcover in association with mallee woodland at Round Hill Nature Reserve central-west NSW (photo H. Cogger). 
SA, and by implication continuous with populations of C. spinodomus sp. nov. in southwest NSW. His "Eyre Peninsula" race corresponds to our Group 5 fordi genetic lineage from Eyre Peninsula, however, his "northern" race which included all other populations in the north and west of the state, was a composite of the Group 3 fordi genetic lineage from the Strzelecki and Tarari desert systems and the Group 4 fordi genetic lineage from the Great Victoria Desert.

Edwards et al. (2015) figured the distribution of populations from northwest Victoria and far southeast SA (their C. fordi clade 5) as extending west across the Murray River and bisecting the Group 1 populations in southeast SA and southwest NSW. Reference to the online supplementary data for this publication gives one specimen (listed as 40887) with the coordinates "-34.05 139.1833", which would place it west of the Murray River. Presumably this is the South Australian Museum specimen R40887 which is listed in the museum database as from Morgan Conservation Park, and with those same coordinates. However, Morgan Conservation Park lies $50 \mathrm{~km}$ to the east of these coordinates and on the south and east side of the Murray River. On the assumption the coordinates used to map this specimen are in error, all populations identified by Edwards et al. as belonging to their $C$. fordi clade 5 genetic lineage actually lie entirely to the south and east of the main Murray River channel, and the distribution of this lineage is parapatric to (not bisecting) the C. spinodomus sp. nov. populations in southeast SA and southwest NSW - a result consistent with our morphological investigations.

\section{Discussion}

The association between a number of Australian lizard species and Triodia hummock grass has long been recognized, a feature attributed not only to its structural complexity (Pianka, 1969) but also to its role in providing a "microclimate refuge" (Cogger, 1984) against extremes of temperature and dryness. The extent to which different taxa utilize Triodia varies. For some species it represents a niche within which they exclusively reside across their range, whereas for others it is the preferred niche at certain parts of their distribution. In the interior of southeast Australia five species of lizard, the diplodactylid gecko Strophurus elderi, the pygopods Delma australis and D. butleri, the skink Ctenotus atlas and agamid C. spinodomus sp. nov., are obligate inhabitants of habitat with a groundcover of Triodia, usually on red sand soils, and typically in association with mallee woodland (Cogger, 1984; Sadlier $\&$ Shea, 1989), and referred to as Triodia Mallee vegetation (Bennett et al., 2010). With the exception of C. spinodomus sp. nov., these taxa have distributions that otherwise extend west across the continent, with the populations in areas of southeast Australia representing the eastern extreme of their distribution. Of these only $C$. atlas remains an obligate to Triodia in mallee woodland throughout its range (Wilson \& Swan, 2017). By comparison, C. spinodomus sp. nov. is far more limited in distribution. Not only is it restricted to those biomes in southeast Australia in which Triodia Mallee vegetation is present as one of its key life history traits, but also requires this habitat type be in combination with a red sand substrate which provides nesting and overwintering sites (Cogger, 1974).

The association of $C$. spinodomus sp. nov. with Triodia extends beyond the presence $v s$ absence of hummock grass habitat mallee vegetation to a dependence on particular successional stages of development of Triodia hummocks post-fire. Bennett et al. (2010) identified the species as being more common in landscapes with large amounts of Triodia Mallee vegetation, with the "time window" for greatest cover of spinifex and presence of large healthy hummocks c. 20-50 years post-fire, with a peak at 35 years (Watson et al., 2012), after which densities decline slowly. In inland southeast Australia Triodia Mallee habitat is fragmented, naturally and through clearing. In the Murray Mallee region large fires $(>100,000 \mathrm{ha}$ ) occurred on average every two decades in the period 1972-2007 (Bennett et al., 2010; Haslem et al., 2011). A consequence of large fires is they create an extensive single age class of regenerating Triodia Mallee. Situations where fragments are burnt entirely and there is no internal source for recolonization could result in local extinction of C. spinodomus sp. nov. The population at Round Hill Nature Reserve, studied by Cogger as part his doctoral thesis (1969) and the basis of subsequent publications (1974 and 1978), has been monitored for variations in population size at regular intervals for the past 50 years, and is the subject of an ongoing long-term monitoring of population size now into its 50th year and to be the subject of a separate publication.

The complexity of interaction of $C$. spinodomus sp. nov. with its environment clearly identify it as an extreme habitat specialist with a distribution that relies on the presence of particular attributes of Triodia in the mallee woodlands of the region, attributes which rise and fall with time and which rely on burning events for renewal, and which make the species highly susceptible to variations in the frequency, intensity and patterns of fire events. 
Acknowledgment. We thank Mark Hutchinson and Carolyn Kovach (South Australian Museum) and Paul Doughty and Rebecca Bray (Western Australian Museum) for facilitating the loan of specimens used in the morphological study, Steve Donnellan (South Australian Museum) for the provision of tissue samples used in the genetic study, and Andrew Amey (Queensland Museum) and Paul Doughty for constructive reviews of the manuscript. Edwina Rickard generated the sequence data for the genetic study analyses. Timothy Cutajar produced the map of $C$. spinodomus sp. nov. presented in Fig. 3, and Corin Sadlier assisted with image 7.

\section{References}

Arevalo, E., S. K. Davis, and J. W. Sites Jr. 1994. Mitochondrial DNA sequence divergence and phylogenetic relationships among eight chromosome races of the Sceloporus grammicus complex (Phrynosomatidae) in central Mexico. Systematic Biology 43(3): 387-418.

https://doi.org/10.1093/sysbio/43.3.387

Atlas of Living Australia. 2019. https://www.ala.org.au/

Bennett, A., M. Clarke, S. Avitabile, L. Brown, K. Callister, A. Haslem, and L. Spence-Bailey. 2010. Fire and wildlife in the Mallee: Insights for Conservation and Management, pp. 1-8. https://researchoutput.csu.edu.au/en/publications/fire-and-wildlife-in-the-malleeinsights-for-conservation-and-man

Cogger, H. G. 1967. Reptiles of Australia in Colour, 1st edition. Sydney: A.H. \& A.W. Reed, pp. 112.

Cogger, H. G. 1969. A study of the ecology and biology of the mallee dragon (Amphibolurus fordi) and its adaption to survival in an arid environment. Ph.D. Thesis, Macquarie University.

Cogger, H. G. 1974. Thermal relations of the Mallee dragon Amphibolurus fordi (Lacertilia: Agamidae). Australian Journal of Zoology 22: 319-339. https://doi.org/10.1071/ZO9740319

Cogger, H. G. 1975. Reptiles and Amphibians of Australia, 1st edition. Sydney: A.H. \& A.W. Reed, pp. 584.

Cogger, H. G. 1978 Reproductive cycles, fat body cycles and socio-sexual behaviour in the Mallee dragon Amphibolurus fordi (Lacertilia: Agamidae). Australian Journal of Zoology 26: 653-672.

https://doi.org/10.1071/ZO9780653

Cogger, H. G. 1984. Reptiles in the Australian arid zone. In Arid Australia, ed. H. G. Cogger and E. E. Cameron, pp. 235-252. Sydney: Australian Museum.

Covacevich, J., and P. Couper. 1991. The Reptile records. In An Atlas of Queensland's Frogs, Reptiles, Birds and Mammals, ed. G. Ingram and R. Raven, pp. 45-140. Brisbane: Queensland Museum.

De Queiroz, K. 2007. Species concepts and species delimitation. Systematic Biology 56: 879-886.

https://doi.org/10.1080/10635150701701083

Doughty, P., L. Kealley, and S. C. Donnellan. 2011. Revision of the Pygmy Spiny-tailed Skinks (Egernia depressa speciesgroup) from western Australia, with descriptions of three new species. Records of the Western Australian Museum 26: 115-137. https://doi.org/10.18195/issn.0312-3162.26(2).2011.115-137

Edwards, D. L., J. Melville, L. Joseph, and J. S. Keogh. 2015. Ecological divergence, adaptive diversification, and the evolution of social signalling traits: an empirical study in arid Australian lizards. American Naturalist 186 (6): E144-E161. https://doi.org/10.1086/683658

Hall, T. A. 1999. BioEdit: a user-friendly biological sequence alignment editor and analysis program for Windows 95/98/NT. Nucleic Acids Symposium Series 41: 95-98.
Haslem, A., L. T. Kelly, D. G. Nimmo, S. J. Watson, S. A. Kenny, R. S. Taylor, S. C. Avitabile, K. E. Callister, L. M. SpenceBailey, M. F. Clarke, and A. F. Bennett. 2011. Habitat or fuel? Implications of long-term, post-fire dynamics for the development of key resources for fauna and fire. Journal of Applied Ecology 48: 247-256.

https://doi.org/10.1111/j.1365-2664.2010.01906.x

Hesse, P. P. 2010. The Australian desert dunefields: formation and evolution in an old, flat, dry continent. In Australian Landscapes, ed. P. Bishop and B. Pillans, Geological Society, London, Special Publications, 346: 141-164. https://doi.org/10.1144/SP346.9

Houston, T. F. 1978. Dragon Lizards and Goannas of South Australia. Special Educational Bulletin Series. Adelaide: South Australian Museum, 84 pp.

Kocher, T. D., W. K. Thomas, A. Meyer, S. V. Edwards, S. Paabo, F. X. Villablanca, and A. C. Wilson. 1989. Dynamics of mitochondrial DNA evolution in mammals: amplification and sequencing with conserved primers. Proceedings of the National Academy of Sciences 86: 6196-6200. https://doi.org/10.1073/pnas.86.16.6196

Kumar, S., G. Stecher, and K. Tamura. 2016. MEGA7: molecular evolutionary genetics analysis version 7.0 for bigger datasets. Molecular Biology and Evolution 33(7): 1870-1874. https://doi.org/10.1093/molbev/msw054

McLean, C. A., A. Moussalli, and S. Sass. 2013. Taxonomic assessment of the Ctenophorus decresii complex (Reptilia: Agamidae) reveals a new species of dragon lizard from western New South Wales. Records of the Australian Museum 65(3): 51-63. https://doi.org/10.3853/j.2201-4349.65.2013.1600

Miller, M. A., W. Pfeiffer, and T. Schwartz. 2010. Creating the CIPRES Science Gateway for inference of large phylogenetic trees. In Proceedings of the Gateway Computing Environments Workshop (GCE), 14 Nov. 2010, New Orleans, pp. 1-8. https://doi.org/10.1109/GCE.2010.5676129

Moussalli, A., C. Moritz, S. E. Williams, and A. C. Carnaval. 2009. Variable responses of skinks to a common history of rainforest fluctuation: concordance between phylogeography and paleodistribution models. Molecular Ecology 18: 483-499. https://doi.org/10.1111/j.1365-294X.2008.04035.x

Nedbal, M. A., M. W. Allard, and R. L. Honeycutt. 1994. Molecular systematics of hystricognath rodents: evidence from the mitochondrial 12S rRNA gene. Molecular Phylogenetics and Evolution 3: 206-220. https://doi.org/10.1006/mpev.1994.1023

O'Connor, D., and C. Moritz. 2003. A molecular phylogeny of the Australian skink genera Eulamprus, Gnypetoscincus and Nangura. Australian Journal of Zoology 51(4): 317-330. https://doi.org/10.1071/ZO02050

Pattengale, N. D., M. Alipour, O. R. P. Bininda-Emonds, B. M. E. Moret, and A. Stamatakis. 2010. How many bootstrap replicates are necessary? Journal of Computational Biology 17: 337-354. https://doi.org/10.1089/cmb.2009.0179

Pepper, M., P. Doughty, M. Hutchinson, and S. Keogh. 2011. Ancient drainages divide cryptic species in Australia's arid zone: morphological and multi-gene evidence for four new species of beaked geckos (Rhynchoedura). Molecular Phylogenetics and Evolution 61: 810-822.

https://doi.org/10.1016/j.ympev.2011.08.012

Pianka, E. R. 1969. Habitat specificity, speciation, and species density in Australian desert lizards. Ecology 50: 498-502. https://doi.org/10.2307/1933908

Sadlier, R.A., and G. Shea. 1989. The Reptiles of Mungo National Park and the Willandra Lakes Region. Herpetofauna 19(2): 9-27. 
Saghai-Maroof, M. A., K. M. Soliman, R. A. Jorgensen, and R. W. L. Allard. 1984. Ribosomal DNA spacer-length polymorphisms in barley: Mendelian inheritance, chromosomal location, and population dynamics. Proceedings of the National Academy of Sciences 81(24): 8014-8018.

https://doi.org/10.1073/pnas.81.24.8014

Simon, C., F. Frati, A. Beckenbach, B. Crespi, H. Liu, and P. Flook. 1994. Evolution, weighting, and phylogenetic utility of mitochondrial gene-sequences and a compilation of conserved polymerase chain-reaction primers. Annals of the Entomological Society of America 87(6): 651-701. https://doi.org/10.1093/aesa/87.6.651

Stamatakis, A., P. Hoover, and J. Rougemont. 2008. A rapid bootstrap algorithm for the RAxML web-servers. Systematic Biology 75: 758-771. https://doi.org/10.1080/10635150802429642

Storr, G. M. 1965. The Amphibolurus maculatus species-group (Lacertilia: Agamidae) in Western Australia. Journal of the Royal Society of Western Australia 48(2): 45-54.

Stuart-Fox, D. M., A. F. Hugall, and C. Moritz. 2002. A molecular phylogeny of rainbow skinks (Scincidae: Carlia): taxonomic and biogeographic implications. Australian Journal of Zoology 50: $39-51$.

https://doi.org/10.1071/Z001051
Swan, G. 1990. A Field Guide to the Snakes and Lizards of New South Wales. Winmalee: Three Sisters Productions, 224 pp.

Swan, G., G. Shea, and R. Sadlier. 2004. A Field Guide to Reptiles of New South Wales, 2nd edition. Sydney: Reed New Holland Publishers, $302 \mathrm{pp}$.

Swan, G., R. Sadlier, and G. Shea. 2017. A Field Guide to Reptiles of New South Wales, 3rd edition. Sydney: Reed New Holland Publishers, $328 \mathrm{pp}$.

Thompson, J. D., T. J. Gibson, F. Plewniak, F. Jeanmougin, and D. G. Higgins. 1997. The CLUSTAL X windows interface: flexible strategies for multiple sequence alignment aided by quality analysis tools. Nucleic Acids Research 25: 4876-4882. https://doi.org/10.1093/nar/25.24.4876

Watson, S. J., R. S. Taylor, L. Spence-Bailey, D. G. Nimmo, S. Kenny, L. T. Kelly, A. Haslem, P. Griffioen, K. Callister, L. Brown, S. Avitabile, A. F. Bennett, and M. F. Clarke. 2012. The Mallee fire and biodiversity project. Proceedings of the Royal Society of Victoria 124(1): 38-46. https://doi.org/10.1071/RS12038

Wells, R. W. and C. R. Wellington. 1985. A classification of the Amphibia and Reptilia of Australia. Australian Journal of Herpetology Supplementary Series 1: 1-61.

Wilson, S., and G. Swan. 2017. A Complete Guide to Reptiles of Australia, 5th edition. Sydney: Reed New Holland Publishers, $647 \mathrm{pp}$.

\section{Appendix 1}

Specimen voucher registration number and general location for specimens used in the genetic study, and GenBank accession numbers assigned to sequences generated for these specimens.

\begin{tabular}{|c|c|c|c|c|c|}
\hline \multirow[t]{2}{*}{ taxa } & \multirow[t]{2}{*}{ vouchers } & \multirow[t]{2}{*}{ locations } & \multicolumn{3}{|c|}{ GenBank numbers } \\
\hline & & & $12 \mathrm{~S}$ & $16 \mathrm{~S}$ & ND4 \\
\hline Group 1 C. spinodomus sp. nov. & AMS R.156615 & Yathong NR, NSW & MN136704 & MN136730 & MN136678 and MN136756 \\
\hline Group 1 C. spinodomus sp. nov. & AMS R.160412 & Yathong NR, NSW & MN136705 & MN136731 & MN136679 and MN136757 \\
\hline Group 1 C. spinodomus sp. nov. & AMS R.156711 & Yathong NR, NSW & MN136703 & MN136729 & MN136677 and MN136755 \\
\hline Group 1 C. spinodomus sp. nov. & AMS R.135216 & Warrakoo Stn., NSW & MN136701 & MN136727 & MN136675 and MN136753 \\
\hline Group 1 C. spinodomus sp. nov. & AMS R.135216 & Warrakoo Stn., NSW & MN136702 & MN136728 & MN136676 and MN136754 \\
\hline Group 2 C. fordi s.s. & AMS R.149822 & Comet Vale, WA & MN136692 & MN136718 & MN136666 and MN136744 \\
\hline Group 2 C. fordi s.s. & AMS R.149823 & Comet Vale, WA & MN136693 & MN136719 & MN136667 and MN136745 \\
\hline Group 2 C. fordi s.s. & AMS R.149824 & Comet Vale, WA & MN136694 & MN136720 & MN136668 and MN136746 \\
\hline Group 2 C. fordi s.s. & AMS R.149825 & Comet Vale, WA & MN136695 & MN136721 & MN136669 and MN136747 \\
\hline Group 2 C. fordi s.s. & AMS R.149827 & Comet Vale, WA & MN136696 & MN136722 & MN136670 and MN136748 \\
\hline Group 2 C. fordi s.s. & AMS R.149835 & Bonnie Vale, WA & MN136697 & MN136723 & MN136671 and MN136749 \\
\hline Group 3 C. fordi Strzelecki & AMS R.151649 & Sturt NP, NSW & MN136699 & MN136725 & MN136673 and MN136751 \\
\hline Group 3 C. fordi Strzelecki & AMS R.151703 & Sturt NP, NSW & MN136700 & MN136726 & MN136674 and MN136752 \\
\hline Group 3 C. fordi Strzelecki & AMS R.153035 & Sturt NP, NSW & MN136698 & MN136724 & MN136672 and MN136750 \\
\hline Group 3 C. fordi Strzelecki & SAM R49254 & Frome Downs, SA & MN136712 & MN136738 & MN136686 and MN136764 \\
\hline Group 3 C. fordi Strzelecki & SAM R49255 & Frome Downs, SA & MN136713 & MN136739 & MN136687 and MN136765 \\
\hline Group 3 C. fordi Strzelecki & SAM R42347 & Noble Wells, SA & MN136706 & MN136732 & MN136680 and MN136758 \\
\hline Group $3 C$. fordi Strzelecki & SAM R30255 & Roxby Downs, SA & MN136708 & MN136734 & MN136682 and MN136760 \\
\hline Group 3 C. fordi Strzelecki & SAM R30257 & Roxby Downs, SA & MN136709 & MN136735 & MN136683 and MN136761 \\
\hline Group 4 C. fordi GVD & SAM R32231 & Hallinor Lake, SA & MN136716 & MN136742 & MN136690 and MN136768 \\
\hline Group 4 C. fordi GVD & SAM R32238 & Hallinor Lake, SA & MN136710 & MN136736 & MN136684 and MN136762 \\
\hline Group 5 C. fordi Eyre & SAM R36493 & Courtabie, SA & MN136717 & MN136743 & MN136691 and MN136769 \\
\hline Group 5 C. fordi Eyre & SAM R36494 & Courtabie, SA & MN136711 & MN136737 & MN136685 and MN136763 \\
\hline Group 5 C. fordi Eyre & SAM R49258 & Eyre Peninsula, SA & MN136714 & MN136740 & MN136688 and MN136766 \\
\hline Group 5 C. fordi Eyre & SAM R49259 & Eyre Peninsula, SA & MN136715 & MN136741 & MN136689 and MN136767 \\
\hline Outgroup C. maculatus & SAM R29397 & Denham, WA & MN136707 & MN136733 & MN136681 and MN136759 \\
\hline
\end{tabular}




\section{Appendix 2}

Specimen voucher registration numbers and locations used in the morphological study (note pipe symbol used between specimen registration number(s) and locations).

Group 1-C. spinodomus sp. nov.: see type data.

aff. Group 1-C. aff. spinodomus: AMS R.53878 | 15 miles W of Annuello, VIC 34.78S 142.57E; AMS R.55032 | Gingimrick area, VIC 34.92S 142.65E; AMS R.68785-90 | Hattah, VIC 34.77S 142.27E; AMS R.32774 | Big Desert near Underbool ca. 30 miles along Nhill road, VIC 35.17S 141.80E.

Group 2-C. fordi s.s.: AMS R.149822-23 | Comet Vale, WA 29.95S 121.12E; AMS R. 149824-27 | Comet Vale, sand dunes 2.5 km N Comet Vale, WA 29.92S 121.10E; AMS R.149824 | $17.6 \mathrm{~km}$ W Bonnie Vale Rail Stn. via road $3.8 \mathrm{~km} \mathrm{~N}$ Bonnie Vale, WA 30.80S 120.98E; SAM R29248-51 | 57 km S Menzies, WA 30.11S 121.10E; WAM R115156 | Bungalbin Hill, WA 30.3111S 119.7278E; WAM R126412-13, R.126419| Bungalbin sandplain, WA 30.2975S 119.7406E; WAM R126455 | Bungalbin sandplain, WA 30.2825S 119.7603E; WAM R129294 | Bungalbin sandplain, WA 30.2975S 119.7375E; WAM R141036-39 | Bungalbin Hill, WA 30.4000 119.6328; WAM R126937, R.126940, R.126943 | Goongarrie, WA 30.0500S 121.1500E; WAM R145312 | Goongarrie Station, WA 29.9833S 121.0333E; WAM R145369 | Goongarrie Station, WA 29.9675S 121.0817E; WAM R145372 | Goongarrie Station, WA 29.9675S 121.0064E.

Group 3-C. fordi Strzelecki: AMS R.155335 | Sturt National Park, 1.8 km W (by road) along Whitecatch Gate road, NSW 29.1142S 141.1817E; AMS R.158938 Sturt National Park, $5.7 \mathrm{~km} \mathrm{~W}$ (by road) along Whitecatch Gate road, NSW 29.1311S 141.1492E; AMS R.155491 | Sturt National Park, 21.7 km (by road) W of Binerah Downs Hmstd. on Middle road, NSW 29.0256S 141.3675E; AMS R.155459 Sturt National Park, 21.7 km (by road) W of Binerah Downs Hmstd. on Middle road, NSW 29.0256S 141.3675E; AMS R.151706 | Sturt National Park, 33.1 km W Binerah Downs, NSW 29.0819S 141.2611E; AMS R.154852 Cameron's Corner region, NSW 29.0819S 141.2611E; AMS R.151721, R.154851 Sturt National Park, Cameron's Corner road, 3.4 km N Middle road turnoff, NSW 29.0356S 141.1956E; AMS R.153035 | Sturt National Park, Approx. 3 km E (by road) from Cameron's Corner road, NSW 29.0092S 141.0667E; AMS R.155453 | Sturt National Park, Cameron's Corner road, 12.3 km E Cameron's Corner, NSW 29.0017S 141.0992E; AMS R.151647| Sturt National Park, 15.3 km S Fort Grey, NSW 29.1328S 141.2758E; AMS R.104289-91, R.104293 | Omicron Station, QLD 28.82S 141.27E. AMS R.32818-21 | approx. 23 miles north of Innamincka Bore No.2., SA 28.05S 140.92E; AMS R.70164-67 23 miles N of Innamincka Bore No.2, SA 28.05S 140.92E; AMS R.60237-38 $27 \mathrm{~km} \mathrm{~S}$ of Maree on Leigh Creek road, SA 29.90S 138.22E; AMS R.64295 | near Lake Torrens Homestead, SA 31.65S 138.07E; AMS R.59874-75 | Cotabena RS. area, SA 31.70S 138.22E; SAM R42347-48, R42351 1 km (air) NNW of Noble Well, N3/28, SA 30.6333S 139.5333E; SAM R49253-56 | Frome Downs Stn., 1.3 km NE of Lucky Hit Bore, SA 31.4166S 140.0500E; SAM R30254-57 | Olympic Dam Roxby Downs, SA 30.4500S 136.8833E.

Group 4-C. fordi GVD: AMS R.7676a \& b, AMS R.7677a \& b, AMS R.7678a \& b, AMS R.7679 | 407 miles E.W. Line, SA 30.50S 132.15E; AMS R.49578-79 | N Neale Junction Great Victoria Desert, WA 26.13S 126.52E; AMS R.49765, R.49679| 38.1 miles N Neale Junction, WA 27.70S 125.82E; AMS R.49620 | Big Bog, WA 27.33S 126.38E; SAM R14999A-D, R.14999F-K | 7 km W Immarna RS, SA 30.4833S 132.0833E; SAM R32061, R32064, R32085 | 5.5 km S Immarna Siding, SA 30.5519S 132.1450E; SAM R32192, R32199 | 52 km N Muckera R/H, SA 29.5591S 130.1386E; SAM R32225-26, R32229 R32231 R32238 | 44 km SW Halinor Lake, SA 29.4930S 130.1641E.

Group 5-C. fordi Eyre: AMS R.39383 | 20 miles E Kimba-Port Augusta on Eyre Highway, SA 32.22 137.53; SAM R36493-94 | 4.5 km NW Courtabie, SA 33.1791S 134.8222E; SAM R36505 | 7.5 km N Courtabie, SA 33.1416S 134.8333E; SAM R36545, R36550 | 7 km N Courtabie, SA 33.1416S 134.8500E; SAM R49257-60 | Whyalla to Kimba road, $25 \mathrm{~km}$ E of Secret Rocks, SA 33.1666S 137.0166E. 